\title{
Proposed stratotype for the base of the Lawsonian Stage (Cambrian Stage 10) at the First Appearance Datum of Eoconodontus notchpeakensis (Miller) in the House Range, Utah, USA
}

\author{
James F. Miller, KeVin R. Evans, Rebecca L. Freeman, Robert L. Ripperdan \& \\ JOHN F. TAYLOR
}

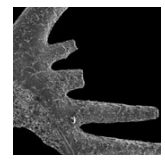

\begin{abstract}
The name Lawsonian Stage is proposed as the highest stage of the Cambrian System (Stage 10). The base of the proposed Lawsonian Stage is at the First Appearance Datum (FAD) of the euconodont Eoconodontus notchpeakensis (Miller, 1969). That horizon, the base of the E. notchpeakensis Subzone of the Eoconodontus Zone, is 3 m above the base of the Red Tops Member of the Notch Peak Formation at the Steamboat Pass section in the House Range, western Utah, USA. The conodont fauna of the Eoconodontus Zone is widespread in North America and occurs in Asia, Australia, Europe, and South America in facies that include cratonic nearshore sandstones, shallow and intermediate-depth platform carbonates, deep-water ramp, continental slope deposits, and deep-ocean radiolarian chert. This horizon lies at or slightly below the top of the Illaenurus trilobite Zone of western North America and within the lower part of the Saukiella junia Subzone of the Saukia Zone in areas east of the Rocky Mountains. These trilobite and conodont faunas can be traced into slope deposits containing cosmopolitan trilobites. The horizon is nearly coincident with the boundary between the Billingsella and the Finkelnburgia calcitic brachiopod Zones; ranges of organophosphatic brachiopods also characterize the horizon. A high-amplitude, negative, carbon-isotope excursion, the HERB Event, occurs in the Eoconodontus notchpeakensis Subzone. This distinctive geochemical signal is known in western Utah, Australia, China, and in poorly fossiliferous slope deposits in Newfoundland, Canada. The proposed boundary fits between two closely spaced sequence-stratigraphic boundaries described from Utah and Texas, USA. - Key words: Cambrian, Furongian, Lawsonian, Stage 10, chronostratigraphy, conodonts, trilobites, brachiopods, carbon isotopes, HERB Event.
\end{abstract}

MilleR, J.F., Evans, K.R., FreEMAN, R.L., RiPPERDAN, R.L. \& TAYLOR, J.F. 2001. Proposed stratotype for the base of the Lawsonian Stage (Cambrian Stage 10) at the First Appearance Datum of Eoconodontus notchpeakensis (Miller) in the House Range, Utah, USA. Bulletin of Geosciences 86(3), 595-620 (14 figures, 1 table). Czech Geological Survey, Prague. ISSN 1214-1119. Manuscript received January 1, 2011; accepted in revised form July 11, 2011; published online August 5, 2011; issued September 30, 2011.

James F. Miller \& Kevin R. Evans, Department of Geography, Geology \& Planning, Missouri State University, Springfield, Missouri 65897,USA; jimmiller@missouristate.edu, kevinevans@missouristate.edu・Rebecca L. Freeman, Department of Earth \& Environmental Sciences, University of Kentucky, Lexington, Kentucky 40506, USA; rebecca.freeman@uky.edu・Robert L. Ripperdan, 1417 Fairbroook Drive, Des Peres, MO 63131, USA; robert.ripperdan@gmail.com • John F. Taylor, Geoscience Department, Indiana University of Pennsylvania, Indiana, Pennsylvania 15701,USA; jftaylor@.iup.edu

The Subcommission on Cambrian Stratigraphy is progressing toward a long-term goal of dividing the Cambrian System into four series and ten stages. The uppermost series of the Cambrian, the Furongian Series, is divided into the lower Paibian Stage, the middle Jiangshanian Stage, and an unnamed Stage 10 at the top of the Cambrian. The Subcommission made a decision to place the base of Stage 10 at the First Appearance Datum (FAD) of the trilobite Lotagnostus americanus (Billings) or another fossil. At the $15^{\text {th }}$ Field Conference of the Cambrian Stage Subdivision
Working Group, Landing et al. (2010) contended that the taxonomic status and global distribution of Lotagnostus americanus are too poorly understood to use that species for defining the base of Stage 10. They proposed, as a superior alternative, that the FAD of the globally distributed euconodont Eoconodontus notchpeakensis (Miller, 1969) be used for defining the base of Stage 10.

Three reports in this volume are outgrowths of the presentation by Landing et al. (2010). Landing et al. (this volume) document problems with using Lotagnostus 

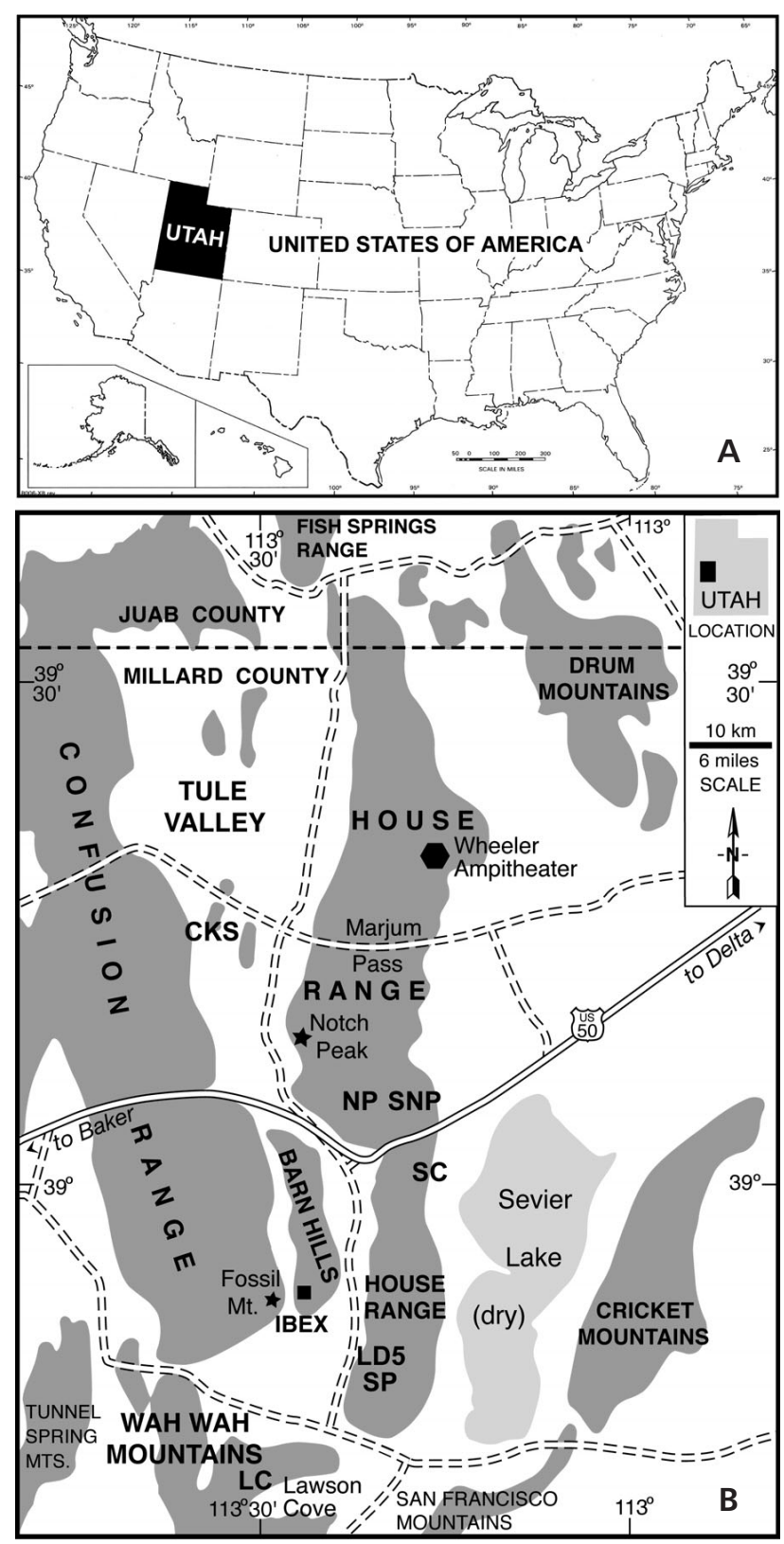

Figure 1. Locations of measured sections that expose Red Tops Member of Notch Peak Formation, Ibex Area, Millard and Juab counties, western central Utah. - A - map of USA showing location of state of Utah. - B - detailed map with insert showing location of detailed area within Utah. Measured sections include LC $=$ Lawson Cove, $\mathrm{SP}=$ Steamboat Pass, LD5 = Lava Dam Five, $\mathrm{SC}=$ Sevier Lake Corral, SNP = Sneakover Pass, NP $=$ Notch Peak, CKS $=$ Chalk Knolls South.

americanus for placing the base of Stage 10. Westrop et al. (this volume) deal with the details of the taxonomy of named species of Lotagnostus that have been considered to be synonyms of L. americanus. In this paper we propose the new name "Lawsonian Stage" for Stage 10 and present evidence that supports using Eoconodontus notchpeakensis as an alternative species for placing the base of
Stage 10 . We present additional data that further characterize the proposed boundary at the FAD of E. notchpeakensis, including ranges of other fossil groups as well as non-biological correlation tools. We identify the proposed stratigraphic horizon, which is in the lower part of the Red Tops Member of the Notch Peak Formation, in several sections in the House Range and nearby areas in western Utah, USA.

\section{Responsibilities of authors}

This report is a joint effort by the authors. J.F. Miller is responsible for the sections on geologic history, stratigraphy, lithofacies, measured sections, and conodonts. Other authors are listed in alphabetical order. K.R. Evans and J.F. Miller are responsible for the section on sequence stratigraphy. R.L. Freeman is responsible for the section on brachiopods. R.L. Ripperdan and J.F. Miller are responsible for the section on carbon-isotope stratigraphy. J.F. Taylor contributed the section on trilobites.

\section{Utah geologic history and locations}

Strata discussed here are exposed in the House Range, northern Wah Wah Mountains, Tule Valley, and Drum Mountains, all located in Millard County, west-central Utah, USA (Fig. 1).

The area, which often is referred to as the Ibex area, has a complex geologic history. During late Neoproterozoic time, rifting of the Panotia supercontinent resulted in formation of a sea-floor spreading ridge along the western margin of Laurentia (Sears \& Price 2003). A tropical, miogeoclinal carbonate platform formed after this rifting, and rapid subsidence produced accommodation for up to $3.87 \mathrm{~km}$ of Cambrian strata (Hintze \& Kowalis 2009, Miller et al. in press a). These miogeoclinal deposits extend westward and grade into mixed carbonate and siliciclastic slope deposits in south-central Nevada (Cook \& Taylor 1977, Cook et al. 1989). Utah strata were thrust eastward during the Cretaceous Sevier Orogeny. Late Neogene Basin and Range extensional faulting produced the horst-and-graben pattern visible on Fig. 1. Today, the area is a desert in which the predominantly carbonate strata of the Furongian Series crop out over a large area as slopes, ledges, and prominent cliffs (Fig. 2).

The large area shown on Fig. 1B is owned collectively by the American people and is administered by the U.S. Bureau of Land Management, and no special permission is needed to visit this area. There are no permanent inhabitants, and the main use of the land is for grazing sheep during the winter and spring. A dense network of gravel 


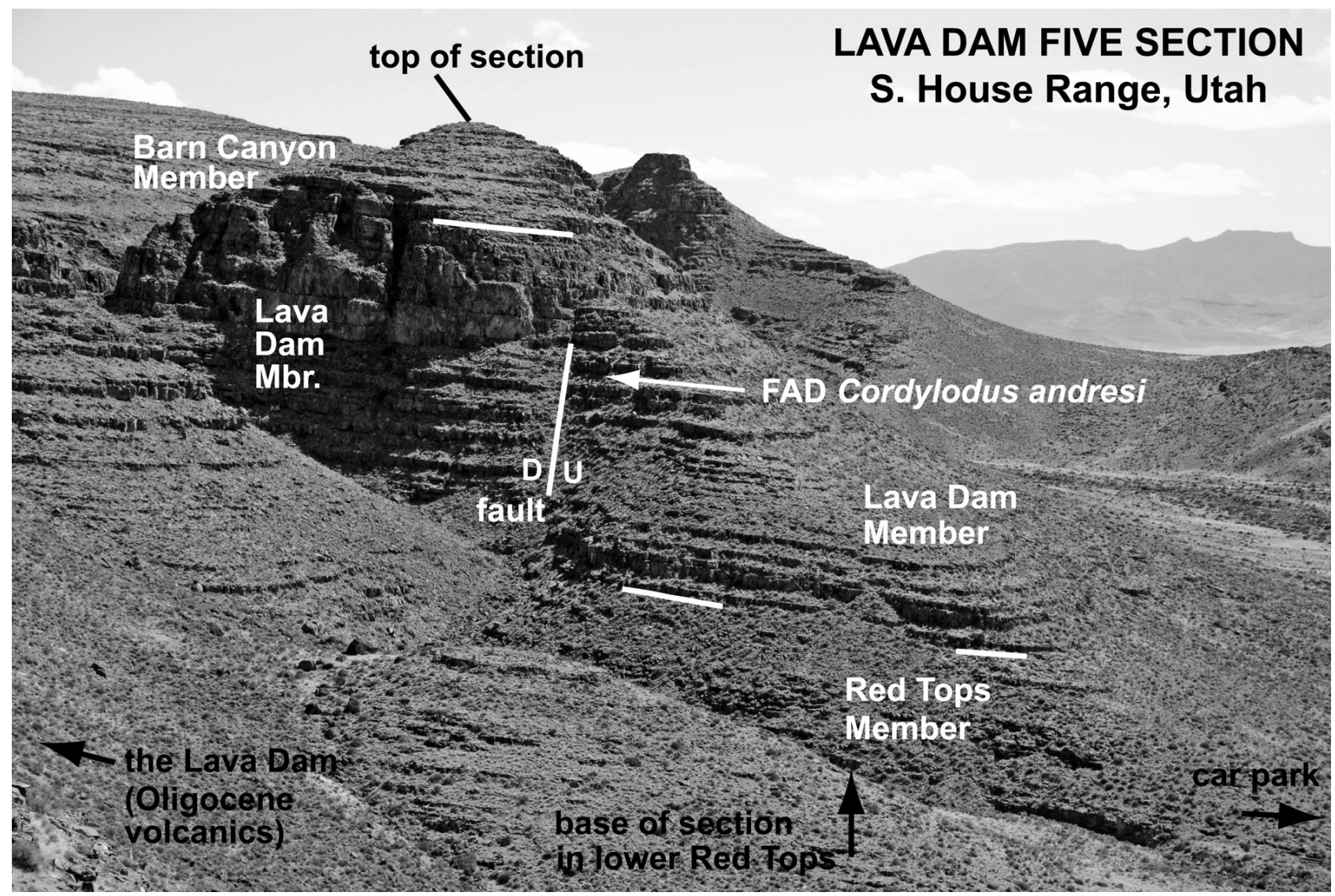

Figure 2. View toward south of Lava Dam Five section (see Fig. 1 for location) showing slopes, ledges, and cliffs typical of Furongian strata in this area. Strata exposed include all except lower 3-4 meters of Red Tops Member, all of Lava Dam Member of Notch Peak Formation, and lower 26 m of Barn Canyon Member of House Limestone. FAD of Cordylodus andresi is indicated; this horizon in this section is the stratotype for the base of the Laurentian Ibexian Series (Cambrian and Ordovician).

roads and dirt tracks provides access to the many sections measured by dozens of geologists studying $\sim 10 \mathrm{~km}$ of Cambrian through Triassic strata during the past 60 years. Fig. 1 shows only a few of the main roads, and an ordinary automobile can be used on the minor roads and most of the dirt tracks. Topographic maps at scales 1:24,000 and $1: 100,000$ cover the entire area, and geologic maps at scales 1:48,000 (e.g., Hintze 1974) and 1:100,000 (e.g., Hintze \& Davis 2002) cover most of the area.

\section{Utah stratigraphy}

Strata of Cambrian Series 3 and of the Furongian Series generally are very fossiliferous in western Utah and include the type areas of the international Drumian Stage (in the Drum Mountains; Fig. 1) and the Laurentian Millardan Series and Ibexian Series (upper Cambrian and lower Ordovician). The Furongian Series is $\sim 600 \mathrm{~m}$ thick and is recorded in the Orr, Notch Peak, and House Formations; their lithostratigraphic and chronostratigraphic classifications are shown on Fig. 3. The base of the Furongian
Series is slightly above the base of the Steamboat Pass Shale Member. The stratigraphic position of the base of the Jiangshanian Stage is unclear because the defining taxon, Agnostotes orientalis (Kobayashi, 1935), is almost unknown in Laurentia. The approximate base of that stage is shown as a dashed line within the upper Steamboat Pass Shale Member, although the correct position may be somewhat higher.

The base of the Ordovician System is shown near the middle of the Barn Canyon Member; the dashed line indicates uncertainty in correlating the base of the Ordovician from the GSSP at Green Point, Newfoundland. Conodonts used to characterize the boundary horizon at Green Point occur in an inverted homotaxial succession and clearly are redeposited, making it impossible to correlate the Green Point GSSP to Utah (Miller et al. 2003, pp. 104-113). At the Green Point stratotype, the base of the Ordovician System is at the lowest occurrence of Iapetognathus fluctivagus Nicoll, Miller, Nowlan, Repetski \& Ethington, 1999, at the base of the Iapetognathus Zone. That biostratigraphic horizon is present in several sections in the Ibex area, Utah. 


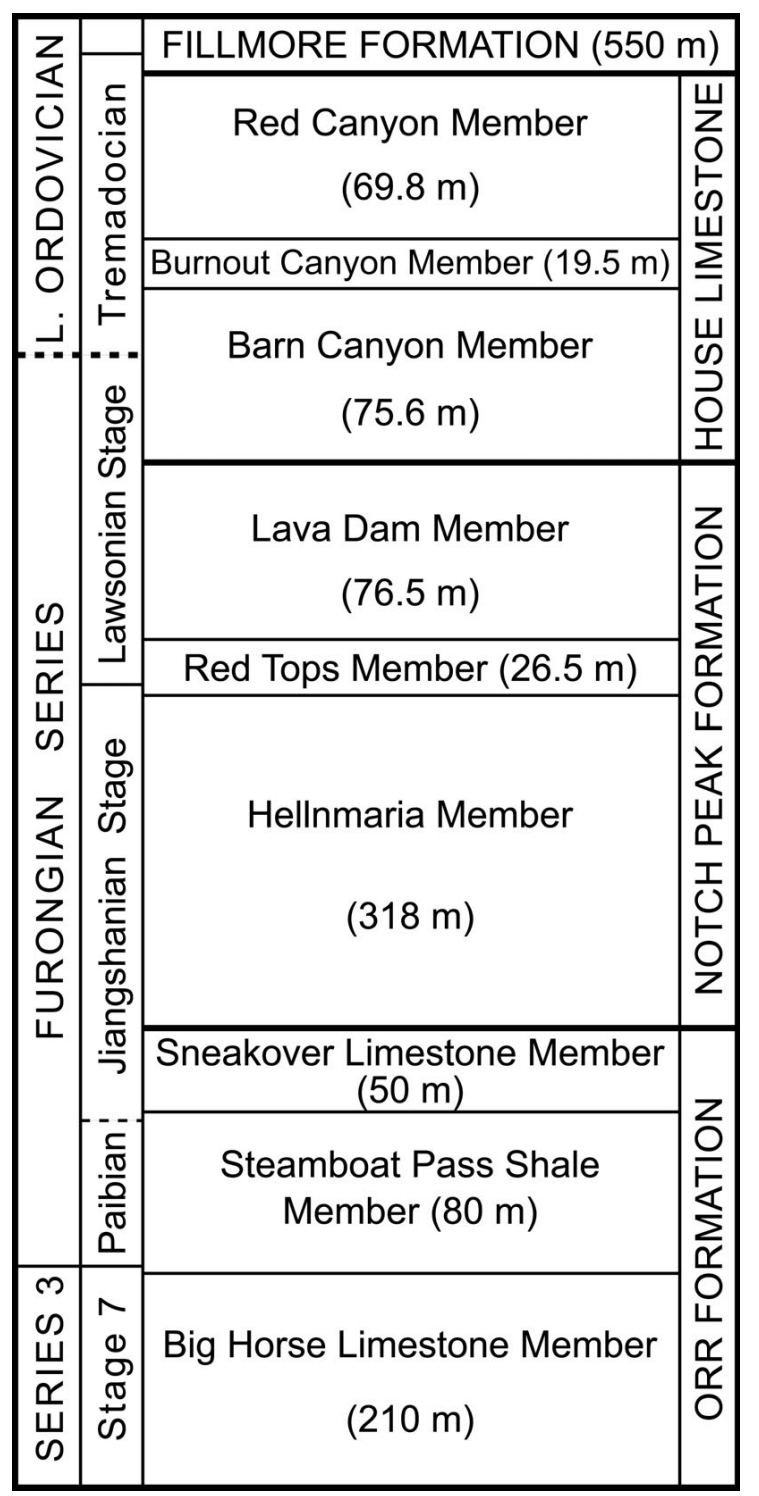

Figure 3. Lithostratigraphic and chronostratigraphic classification of upper part of Cambrian Series 3 and of Furongian Series and of lower part of Lower Ordovician in northern Wah Wah Mountains and southern House Range, western Utah. Uncertain positions of base of Jiangshanian Stage and of Ordovician System are discussed in text.

\section{Lithofacies of the Notch Peak Formation}

Walcott (1908a, b) named the Notch Peak Formation, and Hintze (1951) named the House Limestone. Hintze et al. (1988) named the Hellnmaria, Red Tops, and Lava Dam members (Fig. 3), and Miller et al. (2001) revised those members slightly and named members of the House Limestone. Miller et al. (2003) discussed the lithofacies, biostratigraphy, and sequence stratigraphy of the Notch Peak and House Formations. That report includes detailed descriptions of 17 measured sections totaling $2.98 \mathrm{~km}$ in thickness; all sections have thickness numbers painted on them. The horizon proposed as the GSSP for the base of the Lawsonian Stage is in the lower part of the Red Tops Member. The locations of most of the sections that include the Red Tops Member are shown on Fig. 1.

The Notch Peak Formation is entirely carbonate strata. The Hellnmaria Member, the lower member of the formation, includes dolomite and limestone in the Lawson Cove (LC on Fig. 1) and Steamboat Pass (SP) sections but is entirely limestone farther north in the Sneakover Pass (SNP), Notch Peak (NP), and Chalk Knolls South (CKS) sections. Stromatolites are common in the Hellnmaria Member, and body fossils and conodonts are rare in dolomite facies. Conodonts are common in limestones in the Chalk Knolls area and in the top $13 \mathrm{~m}$ of limestone of the Hellnmaria Member at Steamboat Pass (Miller et al. 2003). Conodont samples from the Chalk Knolls area yielded thousands of organophosphatic brachiopod valves (Freeman \& Miller in press).

The Red Tops Member, the middle member of the Notch Peak Formation, is very fossiliferous, shallow-marine limestone that includes intraclast conglomerates, oöid and trilobite-hash grainstones, and some sections contain a thin stromatolite bioherm. Conodonts useful for biostratigraphy can be obtained from virtually any bed of the Red Tops Member that is not stromatolitic (Miller 1969; Miller et al. 2003, 2006). Trilobites are common and include some silicified faunas; conodont samples have yielded common organophosphatic brachiopods, and calcitic brachiopods are rare. Vendrasco \& Runnegar (2004) described chitons from the Hellnmaria and Red Tops Members at Steamboat Pass.

The Lava Dam Member, the upper member of the Notch Peak Formation, is limestone except in the northern Drum Mountains, where it is dolomite. The lower part of the Lava Dam Member is cherty limestone that records relatively deep subtidal facies. The middle of the member includes shallower lithofacies, including oöid and other grainstones and a widespread, thin stromatolitic biostrome. The upper Lava Dam Member is lime mudstone and thick stromatolitic reefs. Fossils in the Lava Dam Member include common trilobites (which are silicified at several horizons; Adrain \& Westrop 2006), organophosphatic brachiopods (Popov et al. 2002, Holmer et al. 2005), and calcitic brachiopods (Hintze et al. 1988, Miller et al. 2003). Biostratigraphically diagnostic conodonts are abundant and can be obtained from virtually any bed, including stromatolitic reefs.

\section{Evaluation of Utah measured sections}

Seven measured sections that include the Red Tops Member are located on Fig. 1. All of these sections have yielded detailed biostratigraphic information, but some sections 
have flaws that preclude them from consideration as a stratotype section. For example, the Lawson Cove, Sneakover Pass, and Chalk Knolls South sections have thin covered intervals at the critical horizon, and that horizon is slightly below the lowest exposure at Sevier Lake Corral (SC). However, sections at Sneakover Pass, Notch Peak, and Chalk Knolls South document conodont zones of the upper Jiangshanian Stage, and some sections document the upper parts of the proposed Lawsonian Stage, including Lawson Cove, Sevier Lake Corral, and Chalk Knolls South. Data from all of these sections collectively document a stratigraphic interval that extends from far below the base of the proposed Lawsonian Stage upward into the Lower Ordovician.

Sections with the most potential for defining the base of the Lawsonian Stage are in the southern House Range at Steamboat Pass (SP) and Lava Dam Five (LD), sections that are only $2.5 \mathrm{~km}$ apart (Fig. 4). Miller et al. (2003) provided detailed descriptions of both sections. The Steamboat Pass section includes virtually the entire Notch Peak Formation, although it is so thick $(\sim 410 \mathrm{~m})$ that the measured traverse extends across $\sim 1.5 \mathrm{~km}$ (Hintze et al. 1988). The section is accessed from the Steamboat Pass road by driving north $\sim 1 \mathrm{~km}$ up the canyon west of Steamboat Mountain in 4-wheel drive and walking about another kilometer to the base of the measured traverse (Fig. 4). Strata dip a few degrees to the north. Several small faults cross the measured traverse, but they do not present a problem for reconstructing the stratigraphic succession. The upper $13 \mathrm{~m}$ of the Hellnmaria Member, all of the Red Tops Member, and the lower half of the Lava Dam Member are entirely limestone and contain conodonts, trilobites, and brachiopods. Fig. 5 shows ranges of conodonts based on 6335 identified conodont elements (specimens).

The fossiliferous interval exposed below the proposed boundary is thicker at Steamboat Pass than at Lava Dam Five.

The Lava Dam Five section includes all but approximately the lower 3-4 m of the Red Tops Member, the entire Lava Dam Member, and the lower $26 \mathrm{~m}$ of the House Limestone. The section is accessed by driving east from the Tule Valley Road (Fig. 4) on a smooth dirt track for $\sim 1.2 \mathrm{~km}$ and walking $\sim 150 \mathrm{~m}$ to the base of the section. A fault with $\sim 1 \mathrm{~m}$ of offset crosses the measured traverse $40 \mathrm{~m}$ above the proposed boundary horizon. A fault with $\sim 13 \mathrm{~m}$ of offset crosses the section in the middle of the Lava Dam Member (Fig. 2), but the measured traverse was offset across that fault without difficulty. This section has been intensively studied because the base of the Laurentian Ibexian Series is defined there, near the middle of the Lava Dam Member (Ross et al. 1997; Fig. 1 herein).

Fig. 6 shows the ranges of conodonts in the lower to middle parts of the Lava Dam Five section. These ranges are based on 8272 identified elements; the upper part of

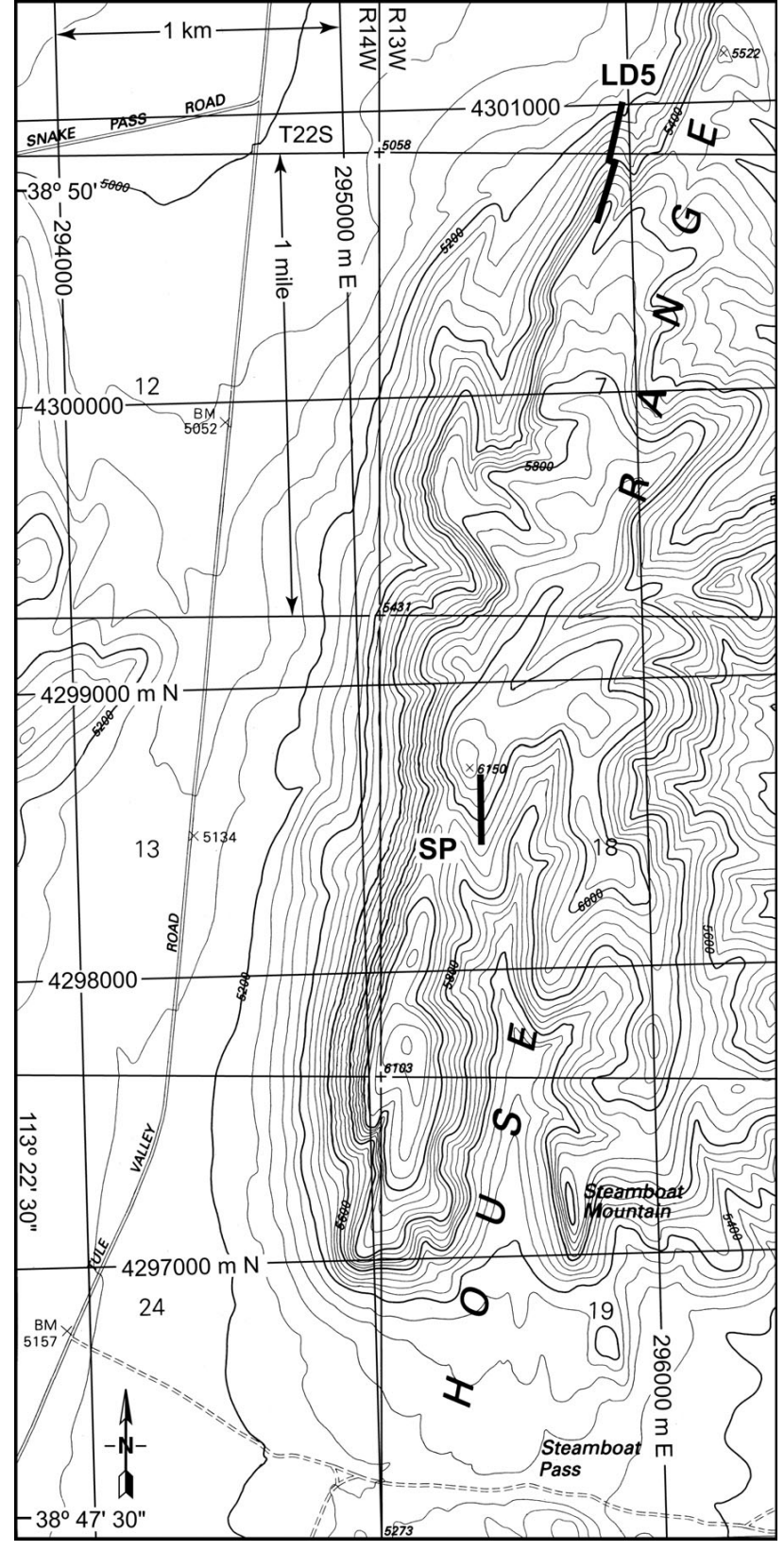

Figure 4. Part of west edge of Red Tops 7.5' topographic quadrangle showing measured traverse of Steamboat Pass measured section (SP) and of Lava Dam Five section (LD5). Note scales for $1 \mathrm{~km}$ and 1 mile. Contour interval is 40 feet $(12.2 \mathrm{~m})$. See Fig. 1 for general location.

the section (not shown on Fig. 6) contains thousands of additional identified elements. Ross et al. (1997, Fig. 5) showed ranges of conodonts and trilobites from the Lava Dam Member and the House Limestone. Exposures include only $2.3 \mathrm{~m}$ of strata below the proposed boundary horizon, a thinner interval than at Steamboat Pass, but Lava Dam Five has more strata exposed above the boundary horizon, including most of the proposed Lawsonian Stage. 
The name "Lawsonian" is derived from the Lawson Cove section in the northern Wah Wah Mountains (Fig. 1). The proposed Lawsonian Stage would be $\sim 160 \mathrm{~m}$ thick, so thick that not all of the interval is exposed in most of the sections in the Ibex area. Strata of the upper part of the proposed Lawsonian Stage, including the base of the Iapetognathus Zone (base of Ordovician System), are exposed at the Lava Dam North section, located about $1 \mathrm{~km}$ north of Lava Dam Five, and at Lawson Cove, Sevier Lake Corral, Chalk Knolls South, and three other sections not shown on Fig. 1. Miller et al. (2003) documented ranges of conodonts throughout the entire interval of the proposed Lawsonian Stage.

\section{Available correlation methods}

The proposed base of the Lawsonian Stage and strata comprising the entire stage can be correlated to other parts of the world using biostratigraphic and non-biostratigraphic methods. Fossil groups that are useful for correlation include conodonts, trilobites, and calcitic and organophosphatic brachiopods. Non-biostratigraphic methods include carbon-isotope stratigraphy and sequence stratigraphy.

\section{Conodonts}

Conodonts are the most useful group for biostratigraphic correlation of the proposed Lawsonian Stage. Three groups of fossils that contain the suffix "conodont" are documented on Figs 5 and 6. Of these three groups, euconodonts are most useful for correlation and are assigned to the genera Cambrooistodus Miller, 1980, Clavohamulus Furnish, 1938, Cordylodus Pander, 1856, Eoconodontus Miller, 1980, Fryxellodontus Miller, 1969, Hirsutodontus Miller, 1969, Proconodontus Miller, 1969, and Teridontus Miller, 1980. Several of these genera were named from the Notch Peak Formation (Miller 1969, 1980), and these faunas are better known in Utah than anywhere else. Most of the other genera on the range charts are paraconodonts, which are not used for biozonation in strata of this age but have potential use for correlation. Protoconodonts are considered to be chaetognath worms or ancestral to them (Szaniawski 2002), and Phakelodus Miller, 1984 is a protoconodont that is very long ranging and currently is not used for correlation.
Conodont zones on the range charts are based on an evolving lineage of species of the euconodonts Proconodontus, Eoconodontus, Cambrooistodus, and Cordylodus (Fig. 7). The Proconodontus tenuiserratus, P. posterocostatus, and $P$. muelleri zones occur in the middle to upper Hellnmaria Member, as shown on Fig. 8; the former two zones are not known at the Steamboat Pass and Lava Dam Five sections but occur in other sections in the area (Miller et al. 2003). The P. muelleri Zone includes the top strata of the Hellnmaria Member and the lowest few meters of the Red Tops Member. Proconodontus muelleri Miller, 1969 is the ancestor of Eoconodontus notchpeakensis (Miller, 1969), and the lowest appearance of the latter species characterizes the base of the Eoconodontus Zone, which is the horizon proposed to characterize the base of the Lawsonian Stage (Figs 8, 9).

The taxonomy and evolutionary relationships among species of Proconodontus and Eoconodontus notchpeakensis are well understood and are not disputed. Proconodontus has a basal cavity that extends nearly to the tip of the element, and it lacks a cusp above the basal cavity (Fig. 7I, J). In the transition to Eoconodontus notchpeakensis, the two distinctly different elements became more slender, the basal cavity became shorter, and a cusp made of white matter formed above the tip of the basal cavity (Fig. 7K-N). Cambrooistodus cambricus (Miller, 1969) appears slightly higher (Fig. 7E, F), and C. minutus (Miller, 1969) still higher (Fig. 7G, H). Proconodontus serratus (Fig. 7C, D) is a less common euconodont species that is also characteristic of the Eoconodontus Zone. Proconodontus tenuiserratus bicostatus Szaniawski \& Bengtson, 1998 has an anterior keel and a serrated posterior keel and is considered to be a junior synonym of Proconodontus serratus Miller, 1969. Proconodontus tenuiserratus bicostatus cannot be assigned to $P$. tenuiserratus Miller, 1980, which lacks such an anterior keel.

It is not necessary to be a conodont specialist to identify these taxa. Conodonts can be obtained from nearly any sample of the Red Tops Member, and accordingly the FAD of E. notchpeakensis has been determined to about a decimeter at both Steamboat Pass and Lava Dam Five. Both types of elements of E. notchpeakensis occur in the lowest sample containing the species at both sections. At Steamboat Pass the FAD of Eoconodontus notchpeakensis is $15.8 \mathrm{~m}$ above the base of the measured section and $3 \mathrm{~m}$ above the base of the Red Tops Member (Figs 5, 9). At Lava Dam Five the FAD of E. notchpeakensis is $2.3 \mathrm{~m}$ above the base of the measured section (Figs 6, 10) within the lower part of the Red Tops Member.

Figure 5. Range chart of conodont species found in Steamboat Pass section and conodont biostratigraphic units based on ranges of species. Short tick marks indicate levels at which the species was found. Numbers of identified elements are shown for each species; total number of elements for all species is 6335. Chronostratigraphic, lithostratigraphic, and sequence stratigraphic units are also shown. S3 $=$ Sequence 3 , S 5A $=$ Sequence $5 \mathrm{~A}$, Seq. $7=\mathrm{Se}-$ quence 7. Base of proposed Lawsonian Stage is at First Occurrence Datum of Eoconodontus notchpeakensis, $15.8 \mathrm{~m}$ above base of measured traverse. 
James F. Miller et al. • Proposed stratotype for the base of the Lawsonian Stage (Cambrian)

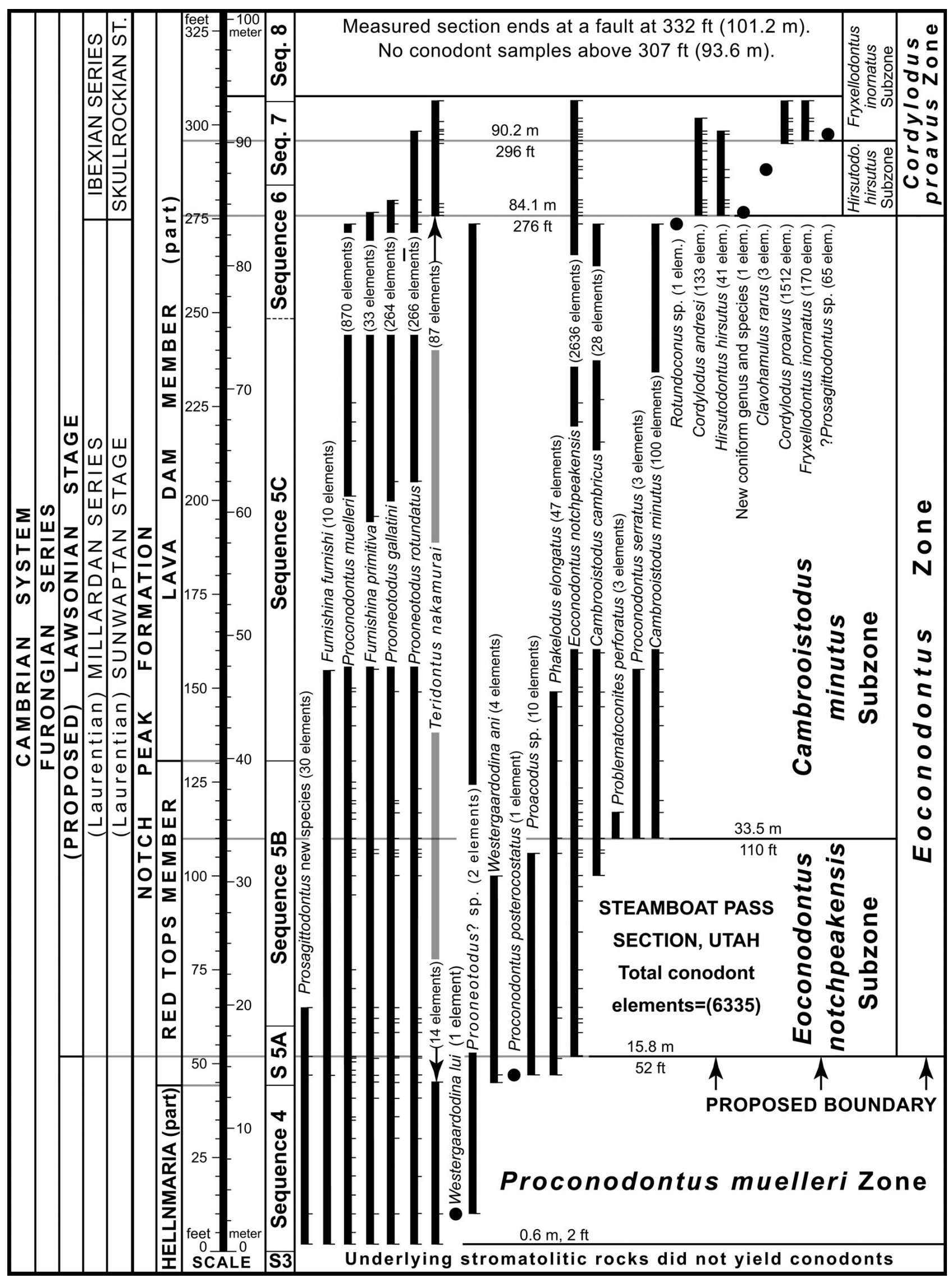


Cordylodus is a somewhat younger genus (Fig. 7A, B), and appearances of successively higher species of that genus are used to name several zones.

Conodont zones on the range charts (Figs 5, 6) are based on common euconodont species, and the numbers of identified elements (specimens) are shown for each species. Cambrooistodus cambricus and Proconodontus serratus are less common euconodont species that are characteristic of the Eoconodontus Zone. Although it does not occur in Utah, Eoconodontus alisonae Landing, 1983 is a species that occurs in slope facies in Newfoundland, Vermont, New York, Maryland, and Kazakhstan and would be useful for recognizing the proposed Lawsonian Stage in slope facies. Barnes (1988, Fig. 8) reported that in the Cow Head Group of Newfoundland, the range of E. alisonae overlaps with Cordylodus and Clavohamulus, which occur above the Eoconodontus Zone. The Cow Head Group is a stratigraphic mélange, and the overlap in ranges of these taxa may be due to redeposition of E. alisonae elements in turbidites and debris slides in these slope sediments.

The early diversification of the Proconodontus-Eoconodontus-Cambrooistodus lineage within the Eoconodontus Zone was interrupted by a mass extinction at the top of that zone (Fig. 8). Following that extinction, a second major faunal diversification began in the Cordylodus proavus Zone. Miller et al. (2006) proposed using the faunal turnover at the base of the Cordylodus proavus Zone at Lawson Cove as the base of Cambrian Stage 10. However, the Subcommission on Cambrian Stratigraphy has expressed concern that use of a horizon this young would make Stage 10 undesirably thin, and they expressed a preference for utilizing the FAD of Cordylodus andresi Viira \& Sergeyeva in Kaljo et al. (1986) for definition of a substage boundary within Cambrian Stage 10 .

Miller \& Repetski (2009) considered three publications that interpreted the base of the Cordylodus proavus Zone (FAD of $C$. andresi) as diachronous. They concluded that such interpretations are incorrect and that this biostratigraphic horizon is very useful for global chronocorrelation. A substage boundary at the base of the Cordylodus proavus Zone would separate very different conodont faunas and would utilize a very correlatable horizon in the middle of the proposed Lawsonian Stage.

Many of the euconodont species used for biozonation are cosmopolitan in their geographic distribution, and they occur in diverse facies and tectonic settings (Miller 1984).
Species of Proconodontus, Eoconodontus, Cambrooistodus, Clavohamulus, Cordylodus, Fryxellodontus, and Hirsutodontus all occur on several continents. Most of those genera occur in North America, South America, Australia, Asia, and Europe, and some have been reported from Antarctica (Büggish \& Repetski 1987). Localities on Fig. 11 are based on strata having one or more of the taxa that are considered to be diagnostic of the Eoconodontus Zone, i.e., from the lower part of the proposed Lawsonian Stage: Cambrooistodus cambricus, C. minutus, Eoconodontus alisonae, Proconodontus serratus, or the occurrence together of P. muelleri and E. notchpeakensis. In Laurentia these faunas are known from slope facies in the USA in western Nevada (Cook et al. 1989), Maryland (Taylor et al. 1996), New York (Landing 1993), and Vermont (Taylor et al. 1991), in Yukon in western Canada (Tipnis et al. 1979, Landing et al. 1980), and from Newfoundland in eastern Canada (Barnes 1988). Faunas diagnostic of the Eoconodontus Zone are known in miogeoclinal carbonate platform deposits on Devon Island in arctic Canada (Nowlan 1985), North Greenland (Kurtz $\&$ Miller 1978), Alberta and Saskatchewan in western Canada (Derby et al. 1972, Westrop et al. 1981, Hein \& Nowlan 1998, including data from drill cores, Godfrey Nowlan, written communication), Quebec in eastern Canada (Godfrey Nowlan, written communication, data from drill cores), in the USA in eastern Nevada (Taylor et al. 1989), western Utah (Miller et al. 2003); from mixed clastic-carbonate shelf deposits in Montana, Wyoming, and Colorado (Taylor \& Miller, unpublished data; Myrow et al. 1999, 2003); cratonic carbonates in Texas (Miller et al. 2003) and New Mexico (Taylor \& Repetski 1995); from carbonates deposited in the Oklahoma aulacogen (Miller $e t$ al. 1982); from nearshore siliciclastic deposits in Iowa, Minnesota, and Wisconsin (Runkel et al. 2007, including data from drill cores); from carbonate shelf deposits in Maryland and northern Virginia (Taylor et al. 1992); and from outer-shelf deposits in New York (Landing, 1993). Outside Laurentia, faunas of the Eoconodontus Zone are known in Argentina (Heredia 1999), Australia (Nicoll \& Shergold 1991), Estonia (Kaljo et al. 1986, Viira et al. 1987), Iran (Müller 1973, Ghaderi et al. 2008), Kazakhstan (Apollonov et al. 1988, Popov \& Tolmacheva 1995, Dubinina 2001), Korea (Lee 2002, Lee et al. 2009), Siberia (Kanygin et al. 1989, Ivata et al. 1997), Sweden (Müller \& Hinz 1991, Szaniawski \& Bengtson 1998), and Turkey

Figure 6. Range chart of conodont species found in Lava Dam Five section and conodont biostratigraphic units based on ranges of species. Short tick marks indicate levels at which the species was found. Numbers of identified elements are shown for each species. Total number of elements for all species is 8272 for part of section illustrated; Ross et al. (1997) showed ranges of additional species based on thousands of additional specimens recovered from upper part of section. Chronostratigraphic, lithostratigraphic, and sequence stratigraphic units are also shown. Seq. $5 \mathrm{~A}=\mathrm{Sequence} 5 \mathrm{~A}$. Base of proposed Lawsonian Stage is at First Occurrence Datum of Eoconodontus notchpeakensis, at $2.3 \mathrm{~m}$ above base of measured traverse. Strata above $62.0 \mathrm{~m}$ comprise the type section of the Laurentian Ibexian Series. 


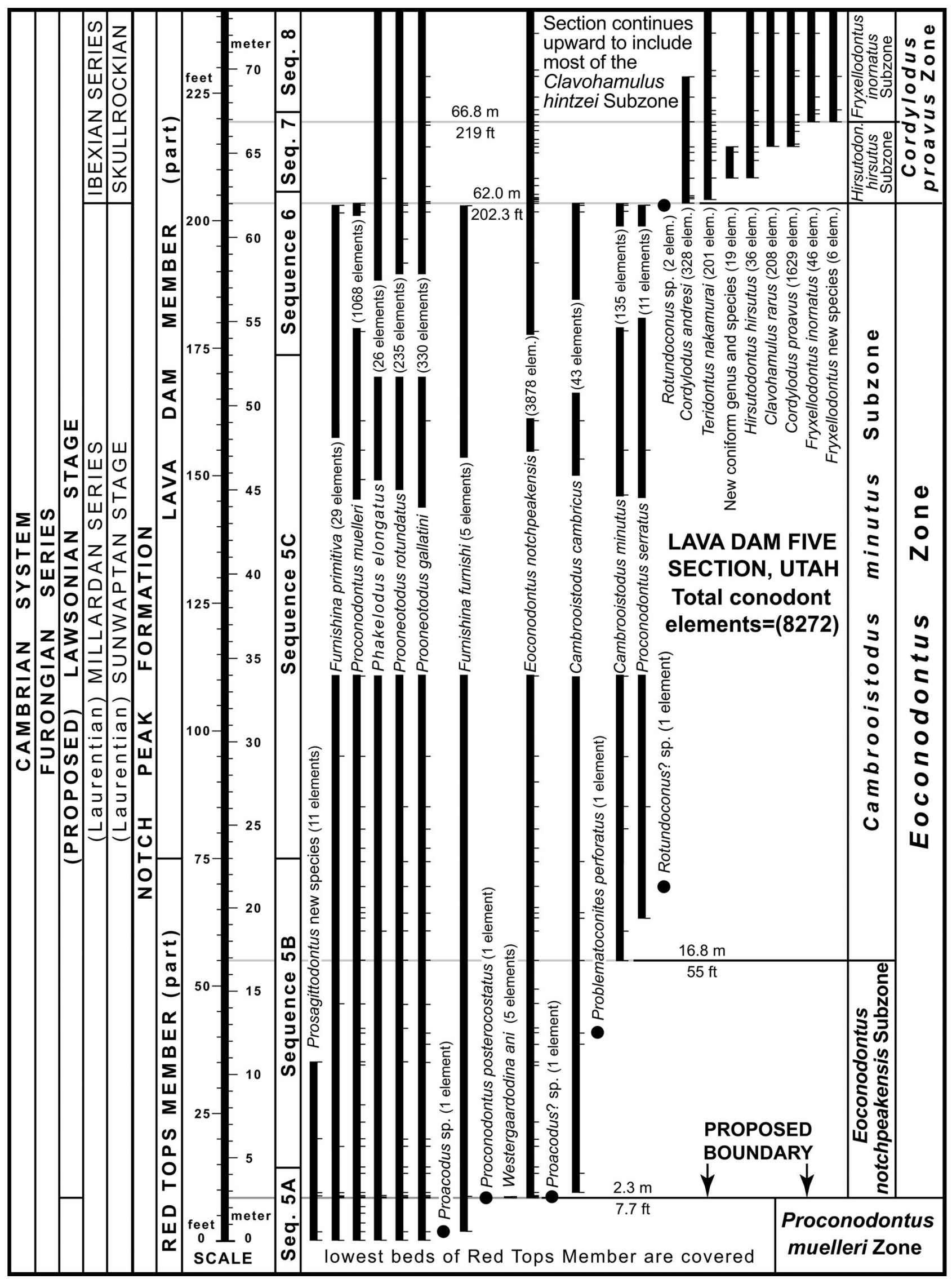




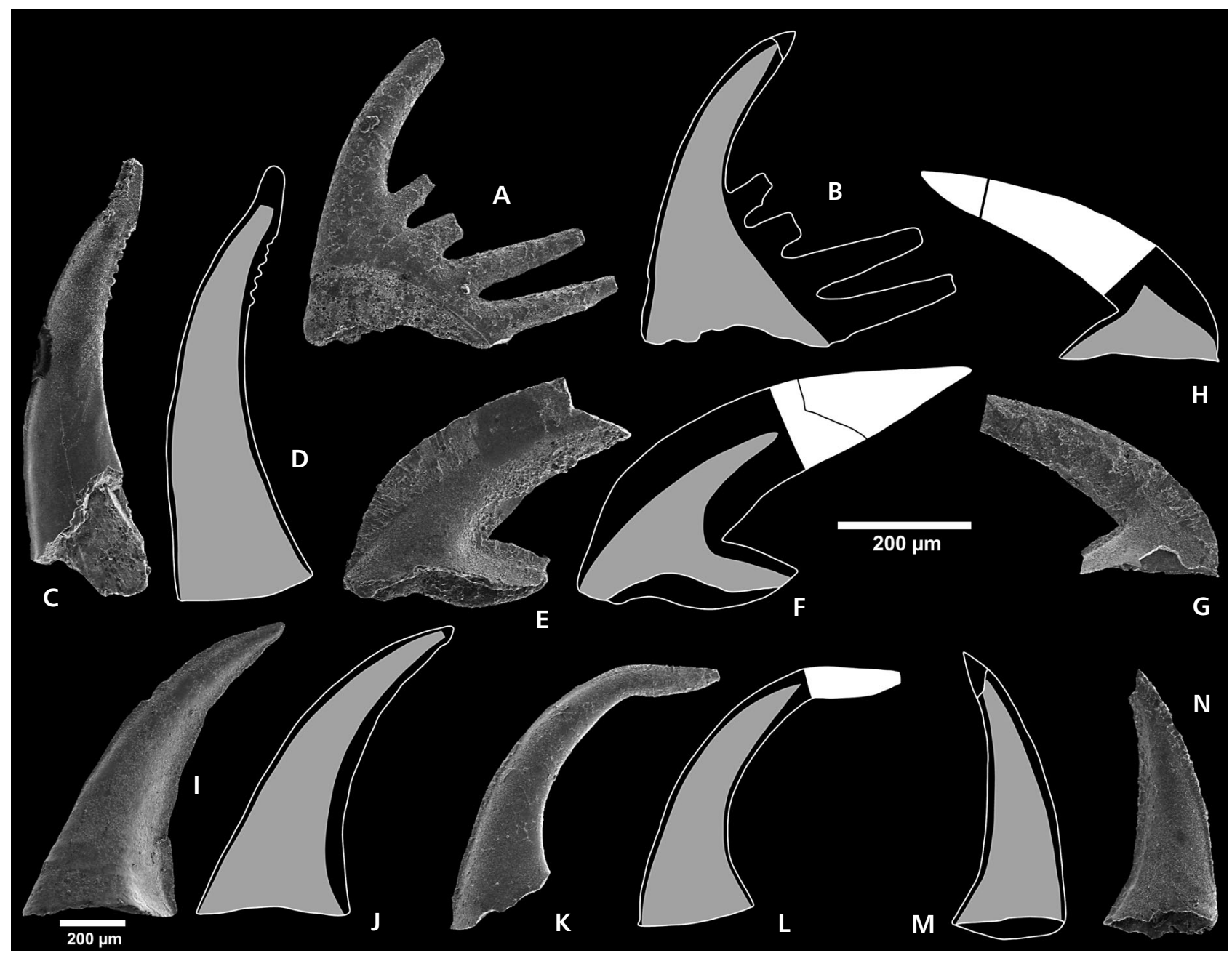

Figure 7. Photomicrographs and line drawings of conodonts characteristic of the proposed Lawsonian Stage. Small scale bar applies to Fig. 7I, J; larger bar scale applies to all other figures. On line drawings, gray area shows shape of basal cavity, white area shows shape of white matter in cusp. Specimens are reposited at the University of Iowa Paleontology Museum (SUI), Iowa City, Iowa, USA. • A, B - Cordylodus andresi, rounded element, SUI 125996, from sample SP-6-49, Lava Dam Member, $84.1 \mathrm{~m}$ above base of Steamboat Pass section (Fig. 8), at base of Cordylodus proavus Zone. • C, D - Proconodontus serratus, SUI 125991, from sample SP-RT-110, Red Tops Member, $33.5 \mathrm{~m}$ above base of Steamboat Pass section (Fig. 8), at base of Cambrooistodus minutus Subzone. E, F - Cambrooistodus cambricus, geniculate element, SUI 125994, from sample LD5-LD-131, Lava Dam Member, $61.9 \mathrm{~m}$ above base of Lava Dam Five section (Fig. 9), from top of Cambrooistodus minutus Subzone. $\bullet$ G, H - Cambrooistodus minutus, geniculate element, SUI 125995, from same sample as E. • I, J - Proconodontus muelleri, SUI 125990, from sample SP-UH-10, upper Hellnmaria Member, $3.0 \mathrm{~m}$ above base of Steamboat Pass section (Fig. 8), from Proconodontus muelleri Zone. • K-N - Eoconodontus notchpeakensis, from sample LD5E-RT-5-15 cm below top of oölite, Red Tops Member, $2.3 \mathrm{~m}$ above base of Lava Dam Five section (Fig. 9), from base of Eoconodontus notchpeakensis Subzone. • K, L - rounded element, SUI 125992, M, N, compressed element, SUI 125993.

(Özgul \& Gedik 1973). Faunas of the Eoconodontus Zone occur in many provinces in China, including Anhui (Dong 1987), Hebei (An 1982), Hubei (Dong 1984), Hunan (Dong et al. 2004), Inner Mongolia (Wang 1984), Jilin (Chen et al. 1988), Liaoning (An 1982), Shandong (Wu et al. 2005), and Zhejiang (Lu \& Lin 1984, Ding et al. 1988). Worldwide, these occurrences are from nearshore sandstones, mixed carbonate and siliciclastic strata, platform and shelf carbonates, organic-rich "stinkstone" concretions, upper and lower slope deposits, and deep-ocean radiolarian cherts. The wide geographic and lithofacies distributions of these conodonts makes them ideal for global correlation, in part because it is possible to tie the base of the Eoconodontus Zone into regional zonal classifications based on other fossil groups, such as trilobites and brachiopods.

Two localities on Fig. 11 are questionable. Landing et al. (2007) described conodonts from the Tinu Formation in Oaxaca, Mexico. These strata were deposited directly on Middle Proterozoic crystalline basement, and the lower $8 \mathrm{~m}$ of their Tu section has exposures of only a few limestone beds. They found Cordylodus andresi $1.3 \mathrm{~m}$ below 


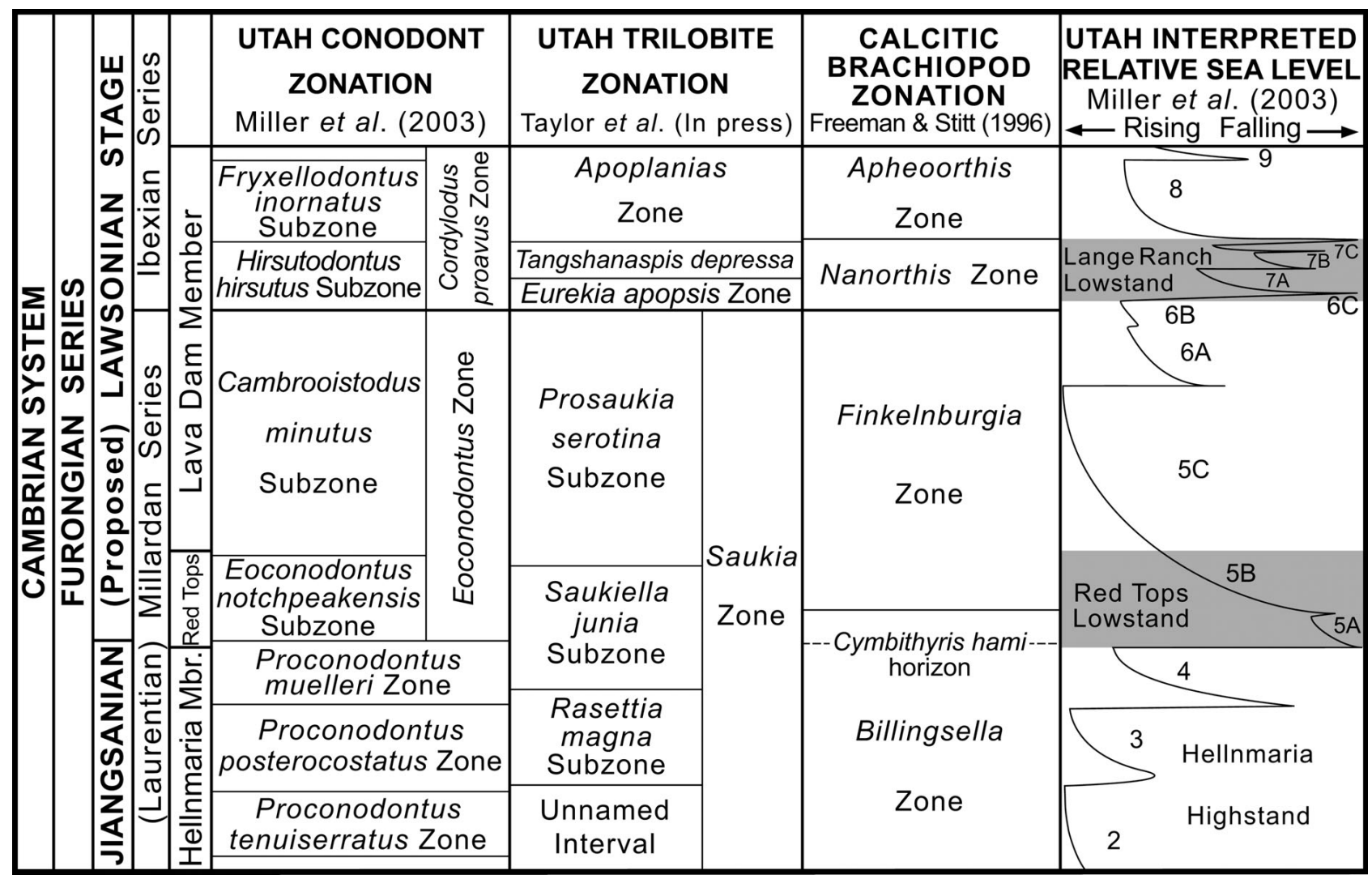

Figure 8. Conodont, trilobite, and calcitic brachiopod biozonations and sequence stratigraphic classification applied to members of the Notch Peak Formation in Utah (see Fig. 3 for more stratigraphic information). Calcitic brachiopod zones were defined in Oklahoma. Base of proposed Lawsonian Stage is base of Eoconodontus Zone. Sequences are indicated by numbers 2-9; divisions of numbered sequences indicated by letters (e.g., 5A, 5B, 5C are divisions of Sequence 5). Shaded areas, Red Tops Lowstand and Lange Ranch Lowstand, indicate intervals of distinctive high-energy strata interpreted as having been deposited during times of relatively low sea level.

the lowest occurrence of Eoconodontus notchpeakensis and interpreted that relationship as indicating conclusively that $C$. andresi occurs near the base of the Eoconodontus Zone in that facies (compare with Figs 5 and 6 herein). Their table 1 indicates that there are few samples with relatively few conodont specimens in the lower part of their Tu section. Their data are far too few to consider that the ranges of these species are well enough established in the Oxaca section to contradict ranges of these species that have been established in many other parts of the world. Proconodontus muelleri occurs in one sample below the lowest occurrence of Cordylodus andresi, so the locality is plotted on Fig. 11, but the age is highly questionable.

The other questionable occurrence on Fig. 11 is in the Tarim Basin, far western China. Jing et al. (2008, fig. 5) used a combination of conodont faunas and carbon-isotope profiles to correlate strata in the Tarim Basin with strata in North China, Australia, Newfoundland, and Lawson Cove, Utah. The conodont taxa that they used are not explained clearly, and thus the locality is marked with question on Fig. 11. However, the correlations of Jing et al. (2008) us- ing carbon-isotope profiles indicate that strata that they studied surely do include the Eoconodontus Zone. Their isotopic correlations are discussed in a later section of this report.

Conodont faunas from what would be from the upper part of the proposed Lawsonian Stage include the Cordylodus proavus Zone (Fig. 8) and the overlying Cordylodus intermedius and Cordylodus lindstromi zones (Miller et al. 2003). Faunas that characterize those zones are known from many more localities worldwide compared to faunas of the Eoconodontus Zone but include the same broad range of depositional environments.

\section{Trilobites}

The position of the base of the Eoconodontus Zone, in the upper half of the Laurentian Sunwaptan Stage, renders its characterization by Laurentian trilobite faunas quite manageable, despite strong biofacies differentiation and associated challenges in accomplishing precise correlation across the lithofacies belts that surrounded Laurentia during the 


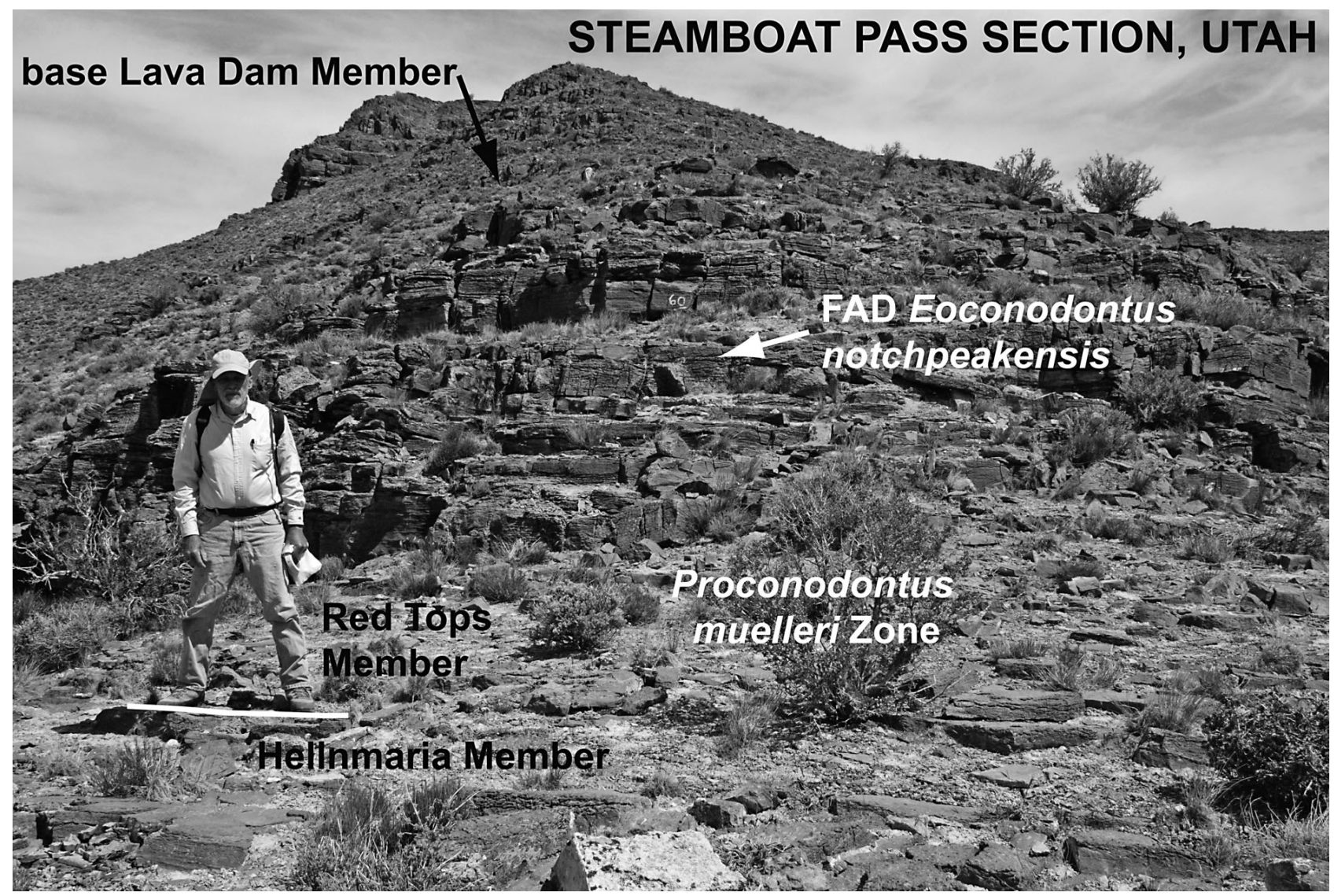

Figure 9. Exposures in Steamboat Pass section, Utah. John Cutler stands at contact between Hellnmaria and Red Tops members, at UTM Zone 12, $0295350 \mathrm{~m}$ E, $4298638 \mathrm{~m}$ N. Contact between Red Tops and Lava Dam Members is not visible in ledges in upper part of section. Lowest strata are assigned to Proconodontus muelleri Zone. Base of proposed Lawsonian Stage is at FAD (First Occurrence Datum) of Eoconodontus notchpeakensis, $3.0 \mathrm{~m}$ above base of Red Tops Member, and overlying strata are assigned to Eoconodontus Zone. Fig. 5 shows ranges of conodonts in this section.

late Furongian. This interval is characterized by rapid speciation within genera assigned to numerous families that are well represented in platform faunas. Eurekiid, dikelocephalid, and ptychaspidid genera (amongst others) display rapid turnover of species through this interval in high-energy, grainstone-rich platform facies (the Euptychaspis-Eurekia Biofacies of Ludvigsen \& Westrop 1983). Plethopeltid and catillicephalid species are similarly short-ranging in microbial-reef-dominated facies through the upper Jiangshanian Stage and lower part of the proposed Lawsonian Stage. Consequently, the proposed stage boundary separates distinctly different trilobite species assemblages that could be used to distinguish Jiangshanian strata from Lawsonian strata in various platform trilobite biofacies.

Conodont faunas that tightly constrain the FAD of Eoconodontus notchpeakensis have been collected from sections with precise trilobite range data in numerous sedimentary basins in North America. Consequently, the position of the base of the proposed Lawsonian Stage is well established within a number of facies-specific successions of trilobite zones and subzones. Such integrated macro- and micro-fossil data are already available from sections deposited across the full environmental spectrum from inner shelf clastics (Runkel et al. 2007), across the full breadth of the carbonate platform (Miller et al. 1982, 2003; Westrop et al. 1981; Orndorff 1988; Taylor et al. 1996, 2009), and into off-platform successions that accumulated in deep water on both the southern (Barnes 1988, Ludvigsen et al. 1989) and northern (Landing et al. 1980, Cook et al. 1989) margins of Laurentia.

Trilobites from the proposed stratotype section at Steamboat Pass include taxa that are helpful in establishing the precise position of the proposed stage boundary within two separate trilobite zonal classifications used for coeval strata in different parts of Laurentian North America. In Texas, Oklahoma, and other areas east of the Rocky Mountains, the Saukia Zone is divided into Rasettia magna, Saukiella junia, and Prosaukia serotina subzones (Fig. 8). In the Rocky Mountains and areas farther west, strata equivalent in age to the $R$. magna Subzone and basal part of the $S$. junia Subzone are assigned to the Illaenurus Zone. Faunas at Steamboat Pass indicate that the base of the Eoconodontus Zone lies at or just slightly below the top of 


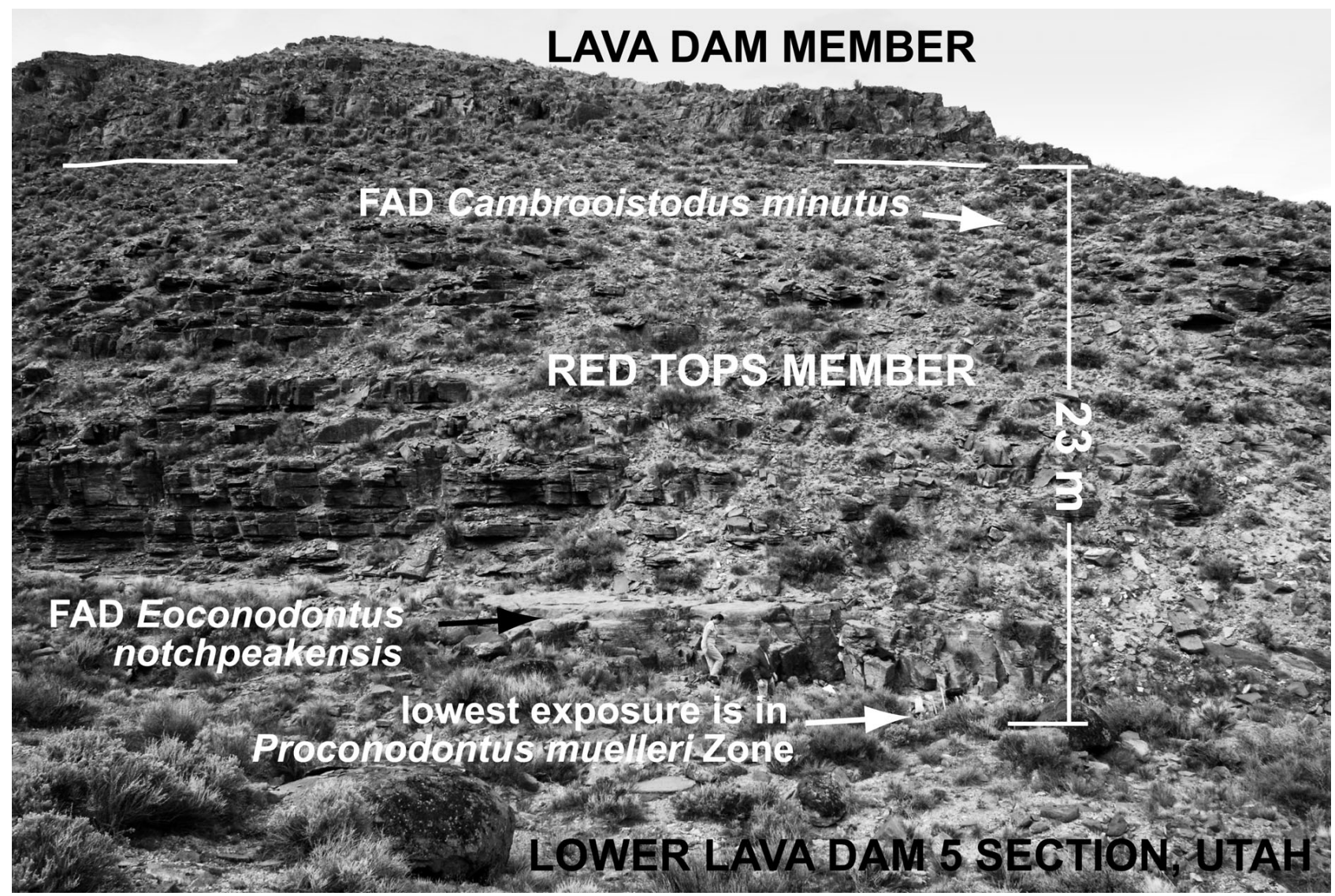

Figure 10. Close-up view of exposures in lower part of Lava Dam Five section; see Fig. 2 for view of entire section. Rebecca Freeman and John Cutler stand near lowest exposure of Red Tops Member, at UTM Zone 12, $0295891 \mathrm{~m} \mathrm{E,} 4301044 \mathrm{~m}$ N. Contact between Red Tops and Lava Dam members is in ledges in upper part of exposure. Lowest strata are assigned to Proconodontus muelleri Zone. Base of proposed Lawsonian Stage is at FAD (First Occurrence Datum) of Eoconodontus notchpeakensis, $2.3 \mathrm{~m}$ above base of section, in lower Red Tops Member, and overlying strata are assigned to Eoconodontus Zone. Fig. 6 shows ranges of conodonts in this section.

the Illaenurus trilobite Zone in western North America (Fig. 12). Collections from the Red Tops Member from below the FAD of E. notchpeakensis include species of Illaenurus, and the uppermost collection, only decimeters below the proposed boundary, includes several taxa characteristic of the Bowmania lassieae Fauna described from the Great Basin by Adrain \& Westrop (2004). Among those species are Eurekia rintintini and Cherrycreekia benjii; the latter species also occurs at the very top of the Illaenurus Zone in Alberta (reported as Acheilus cf. oklahomensis by Westrop 1986). Species from horizons within the basal 10 meters of the Steamboat Pass section compare closely with the taxa reported by Westrop (1986) from the superjacent Proricephalus wilcoxensis Fauna (Fig. 12). Consequently, the top of the Illaenurus trilobite Zone serves as a highly satisfactory proxy for the base of the Eoconodontus Zone in western North America for sections from which conodonts have not been recovered.

The exact position of the age-equivalent horizon within the Saukia Zone in central and eastern North America has been difficult to determine, even with the relatively broad species concepts used by Cambrian biostratigraphers in the late $20^{\text {th }}$ century (Grant 1965, Stitt 1971, Westrop 1986, Hughes \& Hesselbo 1997). The problem of imprecise correlation between eastern and western North America has grown more acute in recent years, as thorough documentation of species morphology based on large silicified collections has resulted in the separation of many broadly defined species into numerous, less variable, and more geographically restricted new species (e.g., Adrain \& Westrop 2004, 2005). Nevertheless, the trilobite data currently available confirm that the top of the Illaenurus Zone of western North America lies somewhere within the lower half of the Saukiella junia Subzone of eastern North America. The data reported herein from Utah are consistent with those from Texas and Oklahoma, where the precise location of the base of the Eoconodontus Zone has been documented in sections with tight trilobite biostratigraphic control (Winston \& Nicholls 1967; Longacre 1970; Stitt 1971, 1977; Miller et al. 1982, in press b). In all of these areas, the base of the Eoconodontus Zone is approximately a third of 


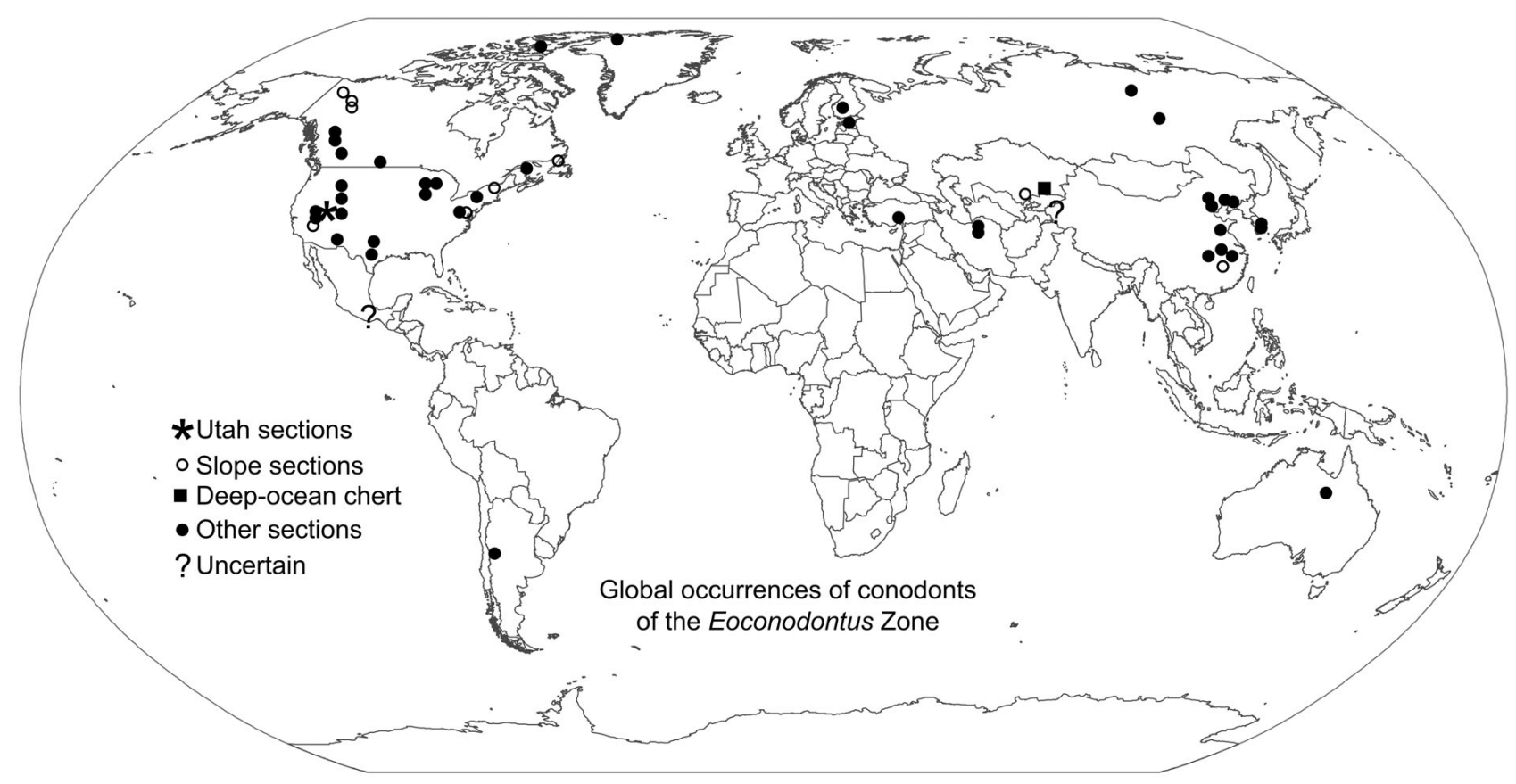

Figure 11. Global occurrences of conodonts diagnostic of the Eoconodontus Zone, the lowest zone of the proposed Lawsonian Stage. Some symbols represent two or more nearby localities. See text for references that document these localities.

the way up into the $S$. junia Subzone above its basal contact with the underlying Rasettia magna Subzone.

Fortunately, the fauna of the Saukiella junia Subzone is not homogenous throughout its vertical extent. Rather, a significant number of new trilobite species appear at approximately the level of the base of the Eoconodontus Zone. Some of these, such as Saukia tumida, Saukia imperatrix, and "Bayfieldia" simata, are broadly defined species that might well be split into multiple species in the future. However, such subdivision would not compromise their utility for distinguishing Lawsonian strata from Jiangshanian strata, because the multiple new species would all still occur only above the proposed boundary between these stages. Similarly, many new species are likely to emerge from such uppermost Jiangshanian taxa as Eurekia granulosa. However, again, the more restricted stratigraphic ranges of the more narrowly defined species would refine, rather than diminish, their utility as stage indicators. Species of ptychaspid genera such as Idiomesus and Euptychaspis also occur as common constituents of the faunas of multiple platform biofacies. Both genera include a number of species whose ranges do not extend above the base of the Eoconodontus Zone, as well as other species whose FAD's lie very close to the base of the proposed Lawsonian Stage (Ludvigsen \& Westrop 1986; Miller et al. 1982, in press b).

Additional sampling is needed to increase the number and size of conodont collections available to establish the precise location of the FAD of E. notchpeakensis along the northern Laurentian margin in northwestern Canada. How- ever, the biostratigraphic data recovered so far from slope facies in that area (Landing et al. 1980, Ludvigsen 1982) confirms that the FAD of E. notchpeakensis lies within the range of the Yukonaspis kindlei Fauna, the interval that is equivalent in age to the Saukiella junia Subzone in platform facies. Consequently, the species of such rapidly evolving deep-water trilobite genera such as Elkanaspis, Larifugula, and Kathleenella hold promise for constraining the base of the proposed Lawsonian Stage in northern Laurentian slope facies. Slope-facies strata in south-central Nevada contain cosmopolitan trilobites, including Charchaqia, Hedenaspis, and Westergaardites, that are associated with conodonts of the Eoconodontus Zone (Cook et al. 1989, fig. 5-3). Such associations of cosmopolitan trilobites with conodonts offer additional potential for intercontinental correlation of the proposed Lawsonian Stage.

Facies rich in microbial reefs are abundant in the Furongian platform carbonates of Laurentia, and certain species of several genera that are common in that facies are restricted to either the upper part of the Jiangshanian Stage or the lower part of the proposed Lawsonian Stage. A distinct contrast in morphology within the genus Rasettia, from species with well impressed furrows such as $R$. magna and $R$. capax in the Jiangshanian, to more effaced Lawsonian species resembling $R$. wichitaensis, would prove useful in positioning the base of the Lawsonian in some areas. Plethopeltid genera, which dominate many Furongian reef faunas, could also assist in positioning the base of the Lawsonian Stage. Plethopeltis stitti is a short-ranging and common species that occurs high in the 


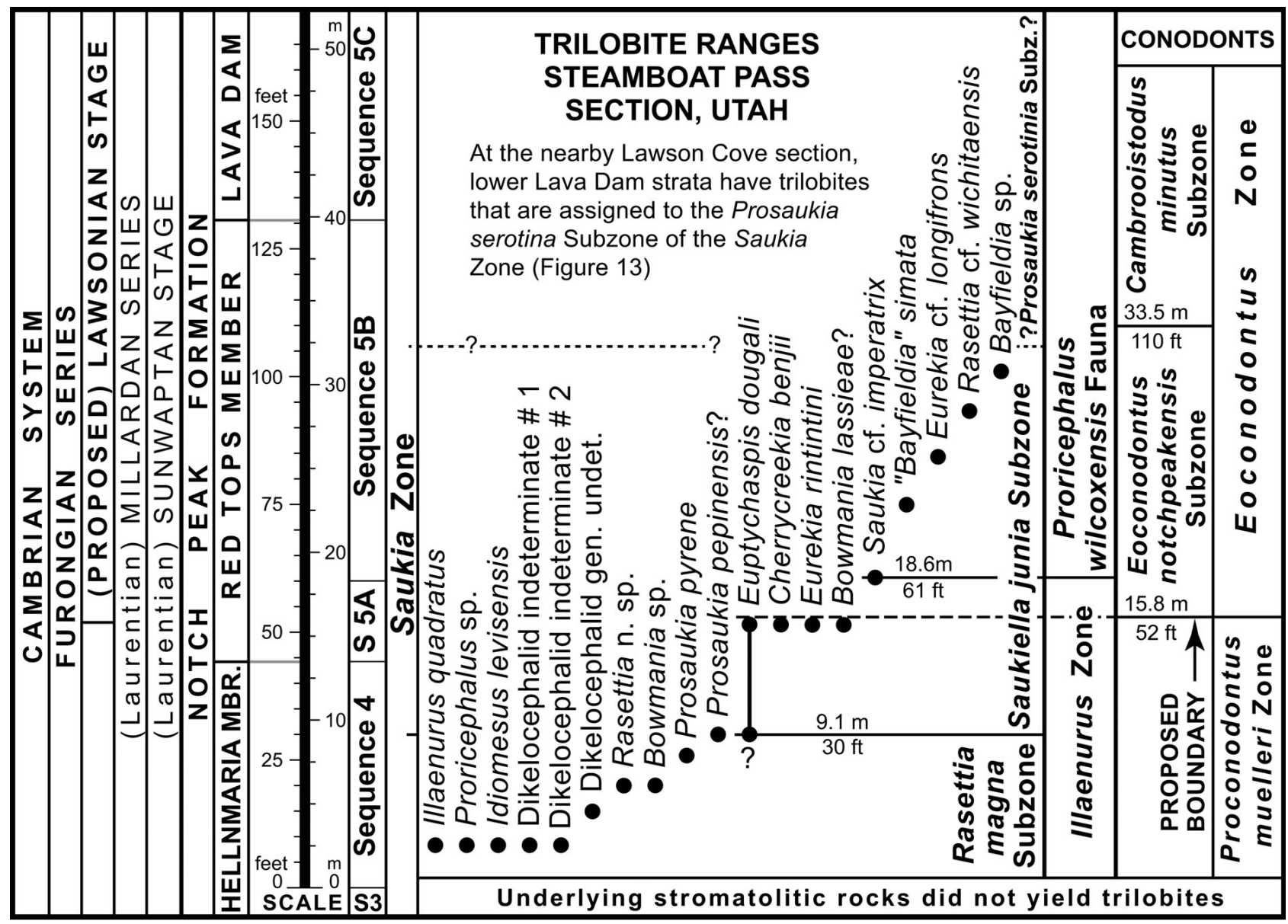

Figure 12. Range chart showing stratigraphic distribution of trilobite species recovered from the proposed stratotype section at Steamboat Pass and positions of zonal and subzonal boundaries relative to the proposed stage boundary.

Jiangshanian Stage across much of southern Laurentia (Stitt 1971; Taylor et al. 1996, 2009). Conversely, Stenopilus latus is a common species that appears very close to the base of the Lawsonian Stage and ranges some distance up into the stage (Miller et al. 1982, in press b). Meniscocoryphe platycephala is perhaps the most promising plethopeltid species for delineation of the base of the Lawsonian in reefal facies where conodonts are sparse or absent; it appears almost exactly at the base of the Eoconodontus Zone in some places and is everywhere restricted to the Lawsonian.

Meniscocoryphe platycephala also extends correlation into the southern Laurentian slope facies, where it is among a relatively small number of trilobites that are restricted to the Keithia schucherti Fauna of Ludvigsen et al. (1989). Therefore, use of the FAD of E. notchpeakensis to define the base of the highest global Cambrian stage would have the beneficial effect of assigning the two highest Cambrian fossil assemblages recognized in deep water faunas from eastern North America, the K. subclavata Fauna and K. schucherti Fauna, to the Jiangshanian and Lawsonian stages, respectively.
Trilobite ranges shown on Fig. 12 are based on data from reconnaissance collecting conducted in May, 2010 to determine the position of the FAD of Eoconodontus notchpeakensis within the trilobite biozonation. Additional collecting will likely produce additional occurrences. Collections did not extend high enough to identify the base of the Prosaukia serotina Subzone (or equivalents in western North America) at Steamboat Pass, but faunas of that subzone are well known at the nearby Lawson Cove section (Fig. 1). Fig. 13 shows ranges of trilobites that are assigned to that subzone at Lawson Cove and also those assigned to overlying trilobite zonal units of the proposed Lawsonian Stage. Miller et al. (2003) showed ranges of even younger trilobites and their zonal assignments from higher parts of the Lawson Cove section.

\section{Brachiopods}

Organophosphatic and calcitic brachiopods in the Notch Peak and House Formations are useful for correlation of 
the proposed Lawsonian Stage. Popov et al. (2002) and Holmer et al. (2005) described organophosphatic brachiopods from these formations and named several new taxa; their ranges and distribution are recorded in range charts and tables in those publications. New collections from the Red Tops and lower Lava Dam Members are available at the Steamboat Pass, Lava Dam Five, Sevier Lake Corral, and Sneakover Pass sections (Fig. 1); their occurrences are recorded in Table 1 herein. Freeman and Miller (in press) described collections totaling more than 6000 valves from the Hellnmaria Member in the Chalk Knolls area. These collections from the Notch Peak and House Formations comprise a brachiopod data set that includes acrotretids and lingulids, and all of the data help to characterize Jiangshanian, Furongian, and lowest Ordovician strata in this area.

Some species reported previously from the Lava Dam Member now are known to occur in older strata. Quadrisonia? lavadamensis Popov et al., 2002 and Zhanatella utahensis Popov et al., 2002 have lowest occurrences in the Hellnmaria Member. They also occur in the Red Tops and lower Lava Dam Members as high as the top of the Cambrooistodus minutus Subzone (Popov et al. 2002). These species characterize the upper Jiangshanian Stage and the lower part of the proposed Lawsonian Stage. The lowest occurrence of Lingulella? incurvata Popov et al., 2002 is in the upper Eoconodontus notchpeakensis Subzone, and its range extends throughout the proposed Lawsonian Stage and into the lowest beds of the Ordovician.

The summit area of Notch Peak Mountain produced specimens that were named "Westonia" notchensis (Walcott, 1908c). Hintze et al. (1988) reported brachiopods from the Red Tops Member near the summit of Notch Peak, and recent study indicates that they are Walcott's species. These and other new collections of that species at Sneakover Pass (Fig. 1) are from the Eoconodontus notchpeakensis Subzone; additional fragments that appear to be the same species occur in the Cambrooistodus minutus Subzone. Study of this material indicates that it is a new genus, and an older species of the same genus occurs in the Hellnmaria Member. Walcott's species appears to characterize the lower part of the proposed Lawsonian Stage.

Eurytreta sublata Popov, 1988 (in Koneva \& Popov, 1988) occurs as low as the upper part of the Hirsutodontus hirsutus Subzone (Fig. 8) at Lava Dam Five, Lawson Cove, and Sneakover Pass. The species ranges nearly to the top of the proposed Lawsonian Stage and characterizes its upper part. This species is the oldest in a lineage of species that occur in miogeoclinal carbonates in Utah. It occurs also in slope deposits in the Malyi Karatau, Kazakhstan. Other brachiopods occur in the same conodont zones in both areas (Popov et al. 2002), suggesting that these organophosphatic brachiopods are useful for intercontinental correlation.

Valves of Wahwahlingula Popov et al., 2002 are relatively common in the Red Tops and Lava Dam Members (Table 1). The material is not assignable to any named species and appears to be a new species that also occurs in the underlying Hellnmaria Member.

Calcitic brachiopods are less common than organophosphatic taxa in the Red Tops and Lava Dam Members, but they can be assigned to the Billingsella, Finklnburgia, and Apheoorthis Zones that Freeman \& Stitt (1996) established in Oklahoma (Fig. 8). Hintze et al. (1988, p. 17) reported Billingsella sp. in the lower part of the Hellnmaria Member where U.S. Highway 50 crosses the House Range (Fig. 1); associated trilobites are from the Drumaspis Subzone of the Idahoia Zone (pre-Saukia Zone). This collection is assigned to the Billingsella Zone (Fig. 8).

Freeman \& Stitt (1996) identified a Cymbithyris hami horizon (Fig. 8) in Oklahoma at the top of the Billingsella Zone at a level that is, within sampling error, exactly at the base of the Eoconodontus notchpeakensis Subzone. This is the oldest Laurentian calcitic brachiopod with a concavo-convex shape, but in most other respects it is similar to Billingsella and may have evolved from it. The species is only known from three sections in Oklahoma, but it is potentially useful for characterizing the base of the proposed Lawsonian Stage.

The Finkelnburgia Zone is documented by two collections in the Red Tops Member (Table 1). One specimen of Finkelnburgia osceola? (Walcott, 1905) is from $6.1 \mathrm{~m}$ above the base of the Lava Dam Five section, and six specimens are from $9.4 \mathrm{~m}$ above the base of the Red Tops Member at Steamboat Pass. These collections are from approximately the same stratigraphic level in the lower Red Tops Member and are from the lower part of the Eoconodontus notchpeakensis Subzone. In Oklahoma the base of the Finkelnburgia Zone (Fig. 8) is in the Eoconodontus notchpeakensis Subzone and in the Saukiella junia Subzone, and the Red Tops material confirms that the base of the Finkelnburgia Zone is in the same position relative to the conodont and trilobite zones in Utah.

Hintze et al. (1988, table 4) reported Billingsella from $32.3 \mathrm{~m}$ in the Steamboat Pass section, in the upper part of the Eoconodontus notchpeakensis Subzone. Recent attempts to resample this horizon to confirm the generic identification produced no additional specimens. A single specimen of Billingsella sp. in the lower Red Tops Member at Sneakover Pass is also in the lower part of the

Figure 13. Range chart showing stratigraphic distribution of trilobite species recovered from the Lower Lawson Cove section and positions of zonal and subzonal boundaries. Names of trilobite zones and subzones are those recommended in Taylor et al. (in press). The Apoplanias and Tangshanaspis depressa (= Tang. depressa) Zones are equivalent to the Parakoldinioidia and Tangshanaspis Zones of Landing et al. (2011). 


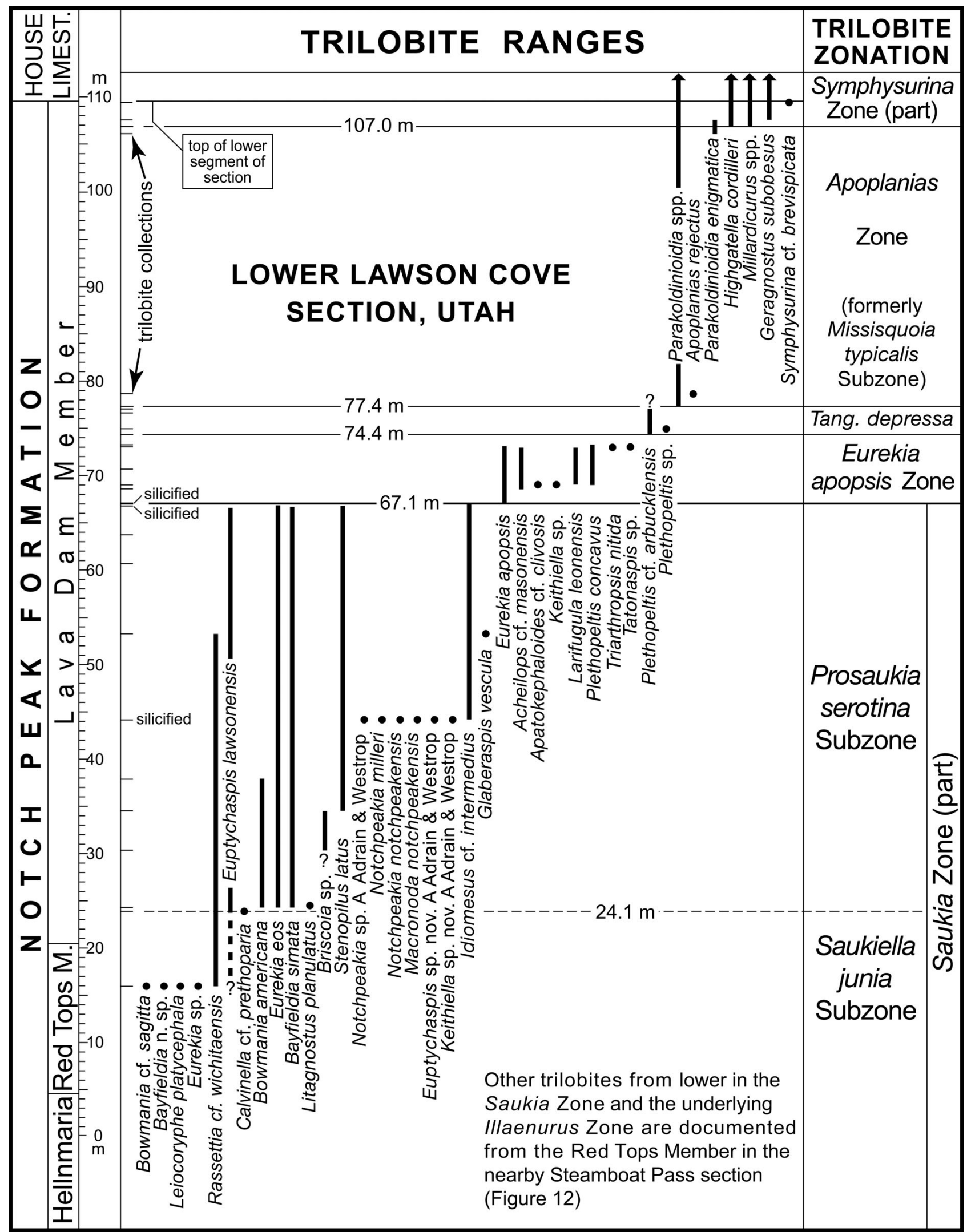


E. notchpeakensis Subzone. These occurrences are slightly higher than the Finkelnburgia occurrences, indicating that the ranges of Billingsella and Finkelnburgia probably overlap in Utah, although they do not in Oklahoma.

The relatively thin Nanorthis Zone succeeds the Finkelnburgia Zone in Oklahoma. However, the lowest occurrence of Nanorthis is associated with Apheoorthis in Utah and is assigned to the Apheoorthis Zone (Fig. 8). Miller et al. (2003, p. 57) reported Apheoorthis oklahomensis Ulrich \& Cooper, 1938 and A. ornata Ulrich \& Cooper, 1936 from $0.6 \mathrm{~m}$ and from a coquina bed $1.2 \mathrm{~m}$ above the base of the Fryxellodontus inornatus Subzone (Fig. 8) at Lawson Cove. Miller et al. (2003) reported Nanorthis hamburgensis (Walcott, 1884), Glyptotrophia imbricata Ulrich \& Cooper, 1936, and rare Syntrophina campbelli (Walcott, 1908c) from a coquina bed at the same stratigraphic position as the Apheoorthis coquina bed at Lawson Cove. Apheoorthis cf. melita (Hall \& Whitfield, 1877) also occurs sporadically in the lower part of the House Limestone at Lawson Cove (Miller et al. 2003, p. 57) and at Lava Dam North, about $1 \mathrm{~km}$ north of the Lava Dam Five section (Jensen 1967). All of these faunas are assigned to the Apheoorthis Zone.

In summary, calcitic brachiopods occur in three zones in Utah. Based on occurrences in Oklahoma and Utah, the Billingsella Zone appears to be characteristic of the Jiangshanian Stage. The Finkelenburgia Zone is characteristic of the lower part of the proposed Lawsonian Stage, and the base of the zone as recognized presently in Utah is only slightly higher than the base of the proposed stage. The Apheoorthis Zone is characteristic of the upper part of the Lawsonian Stage and extends into the overlying Lower Ordovician.

\section{Carbon-isotope stratigraphy}

A high-amplitude, negative carbon-isotope excursion, the HERB Event (Fig. 14), is found in strata assigned to the Eoconodontus notchpeakensis Subzone, and this excursion is a very characteristic feature that occurs slightly above the base of the proposed Lawsonian Stage. Ripperdan et al. (1992) first identified this distinctive isotope excursion in the Black Mountain section in western Queensland, Australia (Fig. 14D), and Ripperdan \& Miller (1995) drew attention to the excursion on carbon-isotope profiles from Black Mountain and from the Lawson Cove section in Utah. Ripperdan (2002) coined the name, HERB Event. Fig. 14 illustrates four carbon-isotope profiles in which the HERB Event is identified and a fifth profile that begins slightly above the HERB Event. Fig. 14A-C are Utah sections at Lawson Cove, Sneakover Pass, and Sevier Lake Corral, which are located on Fig. 1. Fig. 14D is from Black Mountain, in western Queensland, Australia. Fig. 14E is from the lower part of the Green Point section in western Newfoundland, Canada; the GSSP for the base of the Ordovician System is located in that section a few meters higher than the top of the profile. This Green Point profile has not been published previously.

Although there are several high-amplitude cycles of carbon isotopic variation preserved in upper Cambrian sections, the HERB Event is unique in magnitude, with values abruptly falling by approximately 4 per mil in sections at Black Mountain and Green Point and by approximately 2-3 per mil in several other sections. In the Ibex area the HERB Event occurs within the Red Tops Member of the Notch Peak Formation, within the Eoconodontus notchpeakensis conodont Subzone, and within the Saukiella junia trilobite Subzone.

In addition to the large-scale excursion associated with the HERB Event, there is also consistent small-scale variation. A small positive shift in carbon isotopic values occurs near the middle of the Proconodontus muelleri Zone at Sneakover Pass, and a similar positive peak occurs at $\sim 275$ $\mathrm{m}$ on the Black Mountain profile. In both instances the shift follows a prolonged interval where carbon isotopic values remain largely the same. The Lawson Cove profile appears to begin above that positive peak. Above that positive peak, in each section the profile shifts rather consistently toward negative isotopic values and reaches the peak of the HERB Event near the middle of the Red Tops Member in Utah and slightly below the top of the Chatsworth Limestone at Black Mountain. At Green Point the peak of the HERB Event is near the base of Unit 10. The base of the proposed Lawsonian Stage is at the base of the Eoconodontus notchpeakensis Subzone, approximately midway between that positive excursion and the negative HERB Event.

Above the negative peak of the HERB Event, isotopic values in all sections on Fig. 14 shift back toward the positive and then quickly reverse, resulting in a smaller negative peak. This smaller negative peak is near the base of the Sevier Lake Corral profile. Above the secondary peak, isotopic values shift back toward positive values, resulting in a second positive peak near the base of the Cambrooistodus minutus Subzone on profiles from Lawson Cove, Sneakover Pass, and Sevier Lake Corral. That second positive peak is at $\sim 480 \mathrm{~m}$ on the Black Mountain profile and at $\sim 42 \mathrm{~m}$ on the Green Point profile. Discussion of higher parts of these carbon-isotope profiles is beyond the scope of this report, although Miller et al. (2006) discussed correlations of carbon-isotope profiles near the base of the Cordylodus proavus Zone.

The HERB Event and other, slightly younger isotopic peaks are already being used for global correlation. Jing et al. (2008, fig. 5) produced a carbon-isotope profile from the Tarim Plateau in far western China and used conodont biostratigraphy to assist their correlations to other areas. They obtained carbon-isotope profiles from the Dayangcha 
'Table 1. Distribution of brachiopod specimens in samples from Chalk Knolls South (CKS), Lava Dam Five (LD5), Sevier Lake Corral North (SCN), Steamboat Pass (SP), and Sneakover Pass (SNP) sections, western Utah, USA. H = Hellnmaria Member, RT = Red Tops Member, LD = Lava Dam Member, all members of the Notch Peak Formation.

\begin{tabular}{|c|c|c|c|c|c|c|c|c|c|c|c|c|c|c|c|}
\hline \multirow{2}{*}{\multicolumn{2}{|c|}{$\begin{array}{l}\text { Sample number } \\
\text { and measured thickness } \\
\text { in section (in meters) }\end{array}$}} & \multirow[b]{2}{*}{ Conodont Zone or Subzone } & \multicolumn{9}{|c|}{ Phosphatic-shelled brachiopods } & \multicolumn{4}{|c|}{$\begin{array}{c}\text { Calcitic } \\
\text { brachiopods }\end{array}$} \\
\hline & & & 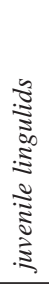 & $\begin{array}{l}\dot{\vec{v}} \\
\stackrel{.}{\Xi} \\
\text { के }\end{array}$ & 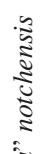 & $\begin{array}{l}\mathbb{\Xi} \\
\stackrel{\Xi}{\Xi} \\
: \\
:\end{array}$ & $\dot{n}$ & 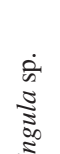 & 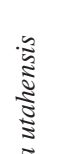 & $\tilde{\Xi})$ & 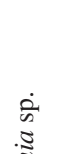 & $\frac{\pi}{\frac{3}{5}}$ & $\dot{m}$ & 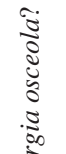 & \\
\hline CKS-RT-111 & $(33.8)$ & Eoconodontus notchpeakensis & 1 & & & & & & & & & & & & 1 \\
\hline CKS-LD-153 & $(46.6)$ & Cambrooistodus minutus & 1 & 2 & & & & & & & & & & & 3 \\
\hline CKS-LD-235.5 & (71.8) & Cambrooistodus minutus & & 1 & & & & & & 5 & & & & & 6 \\
\hline CKS-LD-236 & $(71.9)$ & Cambrooistodus minutus & & & & 1 & & & & & & & & & 1 \\
\hline CKS-LD-237.5 & $(72.4)$ & Cambrooistodus minutus & & & & 1 & & & & & & & & & 1 \\
\hline CKS-LD-240 & (73.2) & Cambrooistodus minutus & & & & & & 1 & & & & & & & 1 \\
\hline CKS-LD-244 & $(74.4)$ & Cambrooistodus minutus & 4 & & & & & & & 58 & & & & & 62 \\
\hline CKS-LD-245 & $(74.7)$ & Cambrooistodus minutus & & & & & & & & & 2 & & & & 2 \\
\hline CKS-LD-247 & (75.3) & Hirsutodontus hirsutus & & & & 1 & & 1 & & & & & & & 2 \\
\hline LD5-RT (-7.5) & $(0.2)$ & Proconodontus muelleri & & 1 & & & 1 & & 2 & & & & & & 4 \\
\hline LD5-RT (-2.5) & $(1.7)$ & Proconodontus muelleri & & & & & & & 1 & $1 ?$ & 1 & & & & 3 \\
\hline LD5-RT (-1) & (2.1) & Proconodontus muelleri & & & & & & 2 & 1 & & & & & & 3 \\
\hline LD5-RT-12 & $(6.1)$ & Eoconodontus notchpeakensis & & & & & & & & & & & & 1 & 1 \\
\hline LD5-RT-56 & $(19.5)$ & Cambrooistodus minutus & & & & & & 1 & 3 & & & & & & 4 \\
\hline LD5-RT-57.5 & $(20.0)$ & Cambrooistodus minutus & & & & & 1 & & & & & & & & 1 \\
\hline LD5-RT-61 & $(21.0)$ & Cambrooistodus minutus & & & & & 2 & & & & & & & & 2 \\
\hline LD5-LD-83 & $(47.2)$ & Cambrooistodus minutus & & & & & & 1 & 2 & & & & & & 3 \\
\hline LD5-LD-130 & $(61.6)$ & Cambrooistodus minutus & & & & & & & & 4 & & & & & 4 \\
\hline LD5-LD-146.5 & $(66.6)$ & Hirsutodontus hirsutus & & & & & & & & & & 1 & & & 1 \\
\hline SCN-RT-10 & $(3.0)$ & Eoconodontus notchpeakensis & 1 & & & & & & & & & & & & 1 \\
\hline SCN-RT-17 & $(5.2)$ & Cambrooistodus minutus & & & & 1 & & & & 21 & & & & & 22 \\
\hline SCN-LD-11 & $(12.8)$ & Cambrooistodus minutus & 1 & & & & & & & & & & & & 1 \\
\hline SCN-LD-128.5 & $(48.6)$ & Cambrooistodus minutus & & & & & & 2 & & 4 & & & & & 6 \\
\hline SCN-LD-147 & $(54.3)$ & Hirsutodontus hirsutus & & & & & & & & & 1 & & & & 1 \\
\hline SCN-LD-149 & $(54.9)$ & Hirsutodontus hirsutus & & & & & & & & & & 25 & & & 25 \\
\hline SCN-LD-153 & $(56.1)$ & Fryxellodontus inornatus & & & & & & 1 & & & & & & & 1 \\
\hline SP-H-2 & $(0.6)$ & Proconodontus muelleri & & & & & & 1 & & & & & & & 1 \\
\hline SP-H-20 & $(6.1)$ & Proconodontus muelleri & & & & & & 1 & & & & & & & 1 \\
\hline SP-RT-47 & $(14.3)$ & Proconodontus muelleri & & & & & & & 3 & & & & & & 3 \\
\hline SP-RT-51.5 & $(15.7)$ & Procondontus muelleri & & & & & & 6 & 3 & & & & & & 9 \\
\hline SP-RT-75 & (22.9) & Eoconodontus notchpeakensis & & & & & & & & & & & & 6 & 6 \\
\hline SP-LD-166 & $(44.2)$ & Cambrooistodus minutus & & & & & & & & & 1 & & & & 1 \\
\hline SP-LD-176 & $(47.2)$ & Cambrooistodus minutus & & & & & & & & & 1 & & & & 1 \\
\hline SNP-H-18 & $(5.5)$ & Proconodontus posterocostatus & & & & & & & 1 & & & & & & 1 \\
\hline SNP-RT-1 & $(34.4)$ & Proconodontus muelleri & & & & & & 1 & & & & & & & 1 \\
\hline SNP-RT-4 & $(35.4)$ & Proconodontus muelleri & & & & & & & 1 & & & & & & 1 \\
\hline SNP-RT-22 & $(40.8)$ & Eoconodontus notchpeakensis & & & & & & 2 & 3 & 2 & & & & & 7 \\
\hline SNP-RT-23 & $(41.1)$ & Eoconodontus notchpeakensis & & & & & & & 2 & & & & & & 2 \\
\hline SNP-RT-26 & $(42.1)$ & Eoconodontus notchpeakensis & & & & & & 1 & & & & & & & 1 \\
\hline SNP-RT-45 & $(47.9)$ & Eoconodontus notchpeakensis & & & 2 & & & & 14 & & & & & & 16 \\
\hline SNP-RT-50 & $(49.4)$ & Eoconodontus notchpeakensis & & & & & & & & & & & 1 & & 1 \\
\hline SNP-RT-109 & $(67.4)$ & Eoconodontus notchpeakensis & & & 4 & & & 5 & & & & & & & 9 \\
\hline SNP-RT-121 & $(71.0)$ & Cambrooistodus minutus & & & & 3 & & & & & & & & & 3 \\
\hline SNP-LD-192 & $(129.2)$ & Hirsutodontus hirsutus & & & & & & & & & & 2 & & & 2 \\
\hline & & TOTALS & 8 & 4 & 6 & 7 & 4 & 26 & 38 & 95 & 6 & 28 & 1 & 7 & 228 \\
\hline
\end{tabular}


section in Jilin Province, China (Ripperdan et al. 1993, Chen et al. 1995), from the Green Point section in Newfoundland, Canada (Cooper et al. 2001), and from the Black Mountain section in Queensland, Australia and the Lawson Cove section in Utah (Ripperdan \& Miller 1995). One of the two profiles from the Tarim Plateau begins slightly below the HERB Event. They clearly used the HERB Event in their correlations of strata from the Tarim Basin, Dayangcha, Green Point, Black Mountain, and Lawson Cove, although they did not use the name "HERB Event".

Recognition of the HERB Event in the Green Point section is especially significant because it illustrates that the boundary horizon for the base of the proposed Lawsonian Stage can be identified in strata with few fossils. Fig. 14E shows that the trilobite Symphysurina cleora occurs in Unit 19 at Green Point, in clasts in a debris-slide breccia (James \& Stevens 1986, p. 145). Barnes (1988, table 6, fig. 9) reported Cordylodus and Eoconodontus notchpeakensis from distal turbidites in Unit 18. No biostratigraphically useful fossils are reported from lower parts of the Green Point section. Nonetheless, the HERB Event is so distinctive that it can be identified in the carbon isotope profile. Jiang et al. (2008) used a different profile from Green Point, but they correlated their highest amplitude negative peak with the HERB Event from Black Mountain and Lawson Cove. The base of the proposed Lawsonian Stage is somewhat lower that the HERB Event at Green Point, perhaps in Unit 5 (Fig. 14E). The ability to identify the approximate level of the base of the Lawsonian Stage in such poorly fossiliferous strata is a powerful asset that enhances the suitability of the FAD of Eoconodontus notchpeakensis for global chronocorrelation.

\section{Sequence stratigraphy}

Miller et al. (2003) divided the Notch Peak and House Formations into 13 sequences; the lowest 4 sequences are in the Hellnmaria Member. Sequences 1-3 collectively comprise an interval that is referred to as the Hellnmaria Highstand (Fig. 8), interpreted as recording a prolonged period of relatively high sea level. Sequence 4 is a thin interval that extends from a lithologic change coinciding with the base of the Proconodontus muelleri Zone and continuing up to the top of the Hellnmaria Member. Sequ- ence 4 (Figs 5, 8) is transitional between the Hellnmaria Highstand and the overlying Red Tops Lowstand, which Miller et al. (2003) identified as coinciding with the Red Tops Member. Lowstand portions of sequences often are recorded as unconformities, but Cambrian strata in western Utah accumulated so rapidly that lowstand deposits are recorded as shallow-marine, high-energy grainstones. The Red Tops Member consists mostly of such lithologies and is divided into Sequence $5 \mathrm{~A}$ and $5 \mathrm{~B}$ (Figs 5, 6, 8). Sequence $5 \mathrm{C}$ is the highstand part of Sequence 5 and includes deep subtidal deposits in the lower Lava Dam Member.

A relative drop in sea level at the top of the Hellnmaria Member (top of Sequence 4) commonly is marked by a thin stromatolite biostrome with a truncation surface at the top. The overlying base of the Red Tops Member records a relative rise in sea level that was brief and ended with a second relative drop in sea level; the thin interval between comprises Sequence 5A. The second regression is marked by a variety of lithologies in the lower Red Tops Member, including thin, recessive beds with evaporite bands at Lava Dam Five and thin tidal-flat deposits at Steamboat Pass and Sneakover Pass. In all three sections these peritidal to supratidal deposits occur between very shallow subtidal oöid grainstones and flat-pebble conglomerates. In central Texas a glauconite greensand occurs at this level in the San Saba Limestone Member of the Wilberns Formation. A relative rise of sea level at the base of Sequence $5 \mathrm{~B}$ is recorded by a thin stromatolite biostrome at Lawson Cove, and in western Colorado a widespread stromatolite unit, the Clinetop Bed, occurs at this level in the Manitou Formation (Myrow et al. 2003). In the Black Mountain section, Australia, an eolian sandstone, the Lily Creek Member of the Chatsworth Limestone, occurs at this level (Nicoll \& Shergold 1991). Miller et al. (2003, pp. 75-78) discussed correlation of some these strata.

The horizon proposed for the base of the Lawsonian Stage is within Sequence 5A, which is only $\sim 5.2 \mathrm{~m}$ thick at Steamboat Pass, $4.3 \mathrm{~m}$ at Lawson Cove, and $7.6 \mathrm{~m}$ at Sneakover Pass. Sequence 5A appears to be widely identifiable, which suggests that it has considerable potential for global correlation of the base of the proposed Lawsonian Stage.

A somewhat higher interval of distinctive lowstand strata, the Lange Ranch Lowstand, occurs in the lower Cordylodus proavus Zone and is identified as Sequence 7

Figure 14. Carbon-isotope profiles that display the HERB Event in the middle of the Eoconodontus notchpeakensis Subzone and coeval strata. A-C are located on Fig. 1; D, E are locations shown on Fig. 11. • A - redrafted and modified from Ripperdan \& Miller (1995). B - unpublished profile; lower part of profile (with data points shown as circles) is from exposures across a valley from upper part (with data points shown as squares). $\bullet \mathrm{C}-$ unpublished profile; exposure begins slightly above interval of HERB Event. $\bullet$ D - redrafted and modified from Ripperdan et al. (1992). $\bullet$ - unpublished profile; occurrence of trilobite Symphysurina from James \& Stevens (1986, p. 142), occurrence of conodonts Cordylodus and Eoconodontus from Barnes (1988, Fig. 9 , Table 6). Horizontal and vertical scales are not uniform among figures; differences affect shapes of profiles. 

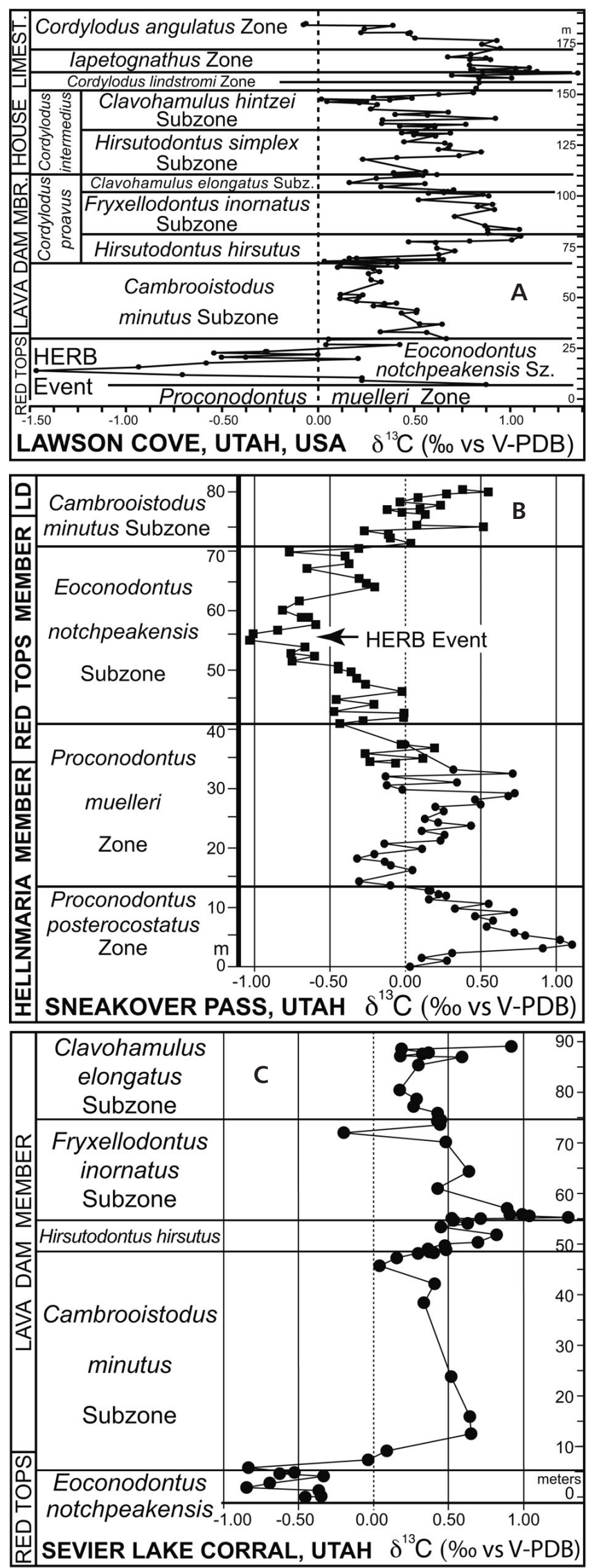
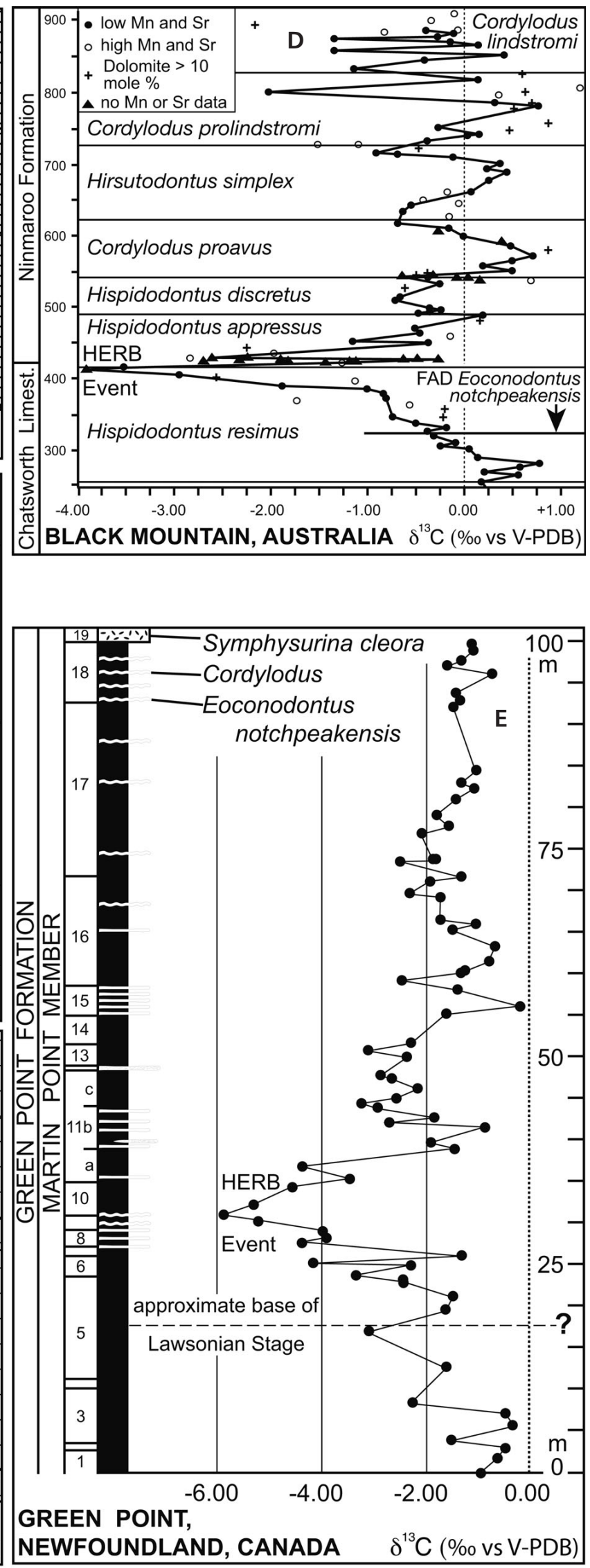
on Figs 5, 6, and 8. Miller et al. (2003) discussed correlation of Sequence 7 in Utah, Texas, and North China, and this distinctive sequence has considerable potential for global correlation of strata in the middle part of the proposed Lawsonian Stage (Miller et al. 2006). Miller et al. (2003) identified other, stratigraphically higher, lowstand deposits that also may be useful for correlation in the upper part of the proposed stage.

\section{Summary}

The name "Lawsonian Stage" is proposed for the highest stage of the Cambrian System (Stage 10). The recommended base of the Lawsonian Stage is at $3.0 \mathrm{~m}$ above the base of the Red Tops Member of the Notch Peak Formation at the Steamboat Pass section in the southern House Range, Utah, USA. This point in rock coincides with the FAD of the euconodont Eoconodontus notchpeakensis (Miller, 1969), at the base of the E. notchpeakensis Subzone of the Eoconodontus Zone. That species and other cosmopolitan conodont species that are diagnostic of the zone occur at many localities in North America, Asia, Australia, Europe, and South America in lithofacies that include nearshore sandstones, mixed clastic and carbonate strata, platform and shelf carbonates, organic-rich "stinkstone" concretions, upper and lower slope deposits, and deep-ocean cherts. Within the E. notchpeakensis Subzone is a distinctive, high-amplitude, negative carbon-isotope excursion, the HERB Event, which has been identified in Australia, Canada, China, and the United States. The HERB Event provides an independent, non-biological horizon for global correlation that is slightly above the base of the proposed Lawsonian Stage, and it can be identified even in poorly fossiliferous strata.

Trilobite and conodont faunas in these Utah strata can be correlated throughout a variety of platform and shelf deposits in North America and into slope deposits that contain cosmopolitan trilobites. Organophosphatic and calcitic brachiopods occur in these strata and provide further criteria for correlation. Sequence stratigraphy is another available correlation tool. The Hellnmaria, Red Tops, and Lava Dam Members of the Notch Peak Formation and the overlying House Limestone all contain conodonts, trilobites, and brachiopods that characterize the Jiangshanian Stage, the proposed Lawsonian Stage, and continue into the Lower Ordovician. The upper Jiangshanian Stage, the entire Lawsonian Stage, and the lower part of the Ordovician are well characterized by carbon-isotope stratigraphy in western Utah.

The base of the proposed Lawsonian Stage and the strata comprising the body of the stage in Utah can be correlated worldwide using several powerful correlation tools.

\section{Acknowledgments}

Ed Landing (New York State Museum, USA) suggested the idea of placing the base of Stage 10 at the FAD of Eoconodontus notchpeakensis. Godfrey Nowlan (Geological Survey of Canada) searched his computer database for localities where conodonts diagnostic of the Eoconodontus Zone are known, and localities he provided in Canada are shown on Fig. 11. John Repetski (United States Geological Survey) provided similar locality information for the eastern United States. Guillermo Albanesi (Universidad Nacional de Córdoba, Argentina) provided similar information for Argentina. Tatiana Tolmachaeva (Russian Research Geological Institute, St. Petersburg) provided similar occurrence data for Russia. Gabriella Bagnoli (Italy) and Hubert Szaniawski (Poland) reviewed the manuscript and made numerous helpful suggestions. M.M. Craig, director of the Electron Microscopy Laboratory at Missouri State University, made the micrographs of conodonts on Fig. 7. John Cutler, Ben Dattilo, and Rachel Nyznyk assisted in collection of trilobites from the Red Tops Member. James D. Loch is acknowledged for help with collection and processing of trilobites from the Lawson Cove section. J.F. Miller's research was funded by National Science Foundation Grants EAR 8108621, EAR 8407281, EAR 8804352, EAR 0642405, and by Faculty Research Grants from Missouri State University. R.L. Freeman's research was supported by the W. Kent McWilliams Geological Research Fund of Tulane University. J.F. Taylor's work on trilobites was funded through grants from the National Science Foundation (EAR-9902812), Faculty Professional Development Committee (FPDC) of the Pennsylvania State System of Higher Education, and the IUP University Senate Research Committee. JFT also acknowledges the donors of the Petroleum Research Fund, administered by the American Chemical Society, for partial support of this research.

\section{References}

Adrain, J.M. \& Westrop, S.R. 2004. A Late Cambrian (Sunwaptan) silicified trilobite fauna from Nevada. Bulletins of American Paleontology 365, 1-56.

Adrain, J.M. \& WestroP, S.R. 2005. Late Cambrian ptychaspidid trilobites from western Utah: Implications for trilobite systematics and biostratigraphy. Geological Magazine 142, 377-398. DOI 10.1017/S0016756805000543

Adrain, J.M. \& Westrop, S.R. 2006. Notchpeakia, a new genus of Upper Cambrian (Sunwaptan) "entomaspidid" trilobites. Journal of Paleontology 80, 1152-1171.

DOI 10.1666/0022-3360(2006)80[1152:NANGOU]2.0.CO;2

AN, T.X. 1982. Study on the Cambrian conodonts from North and Northeast China. Science Reports, Institute of Geoscience, University of Tsukuba, Section B 3, 113-159.

Apollonov, M.K., Chugaeva, M.N., Dubinina, S.V. \& ZhemCHUZHNIKOV, V.G. 1988. Batyrbay section, south Kazakhstan, U.S.S.R. - Potential stratotype for the Cambrian-Ordovician boundary. Geological Magazine 125(4), 445-449.

DOI 10.1017/S0016756800013066

BARNES, C.R. 1988. The proposed Cambrian-Ordovician boundary stratotype and point (GSSP) in western Newfoundland, Canada. Geological Magazine 125(4), 381-414. DOI 10.1017/S0016756800013042 
Buggish, W. \& RePETSKi, J.E. 1987. Uppermost Cambrian (?) and Tremadocian conodonts from Handler Ridge, Robertson Bay Terrane, North Victoria Land, Antarctica. Geologische Jahrbuch 66, 145-185.

Chen, J.Y., Qian, Y.Y., Zhang, J.M., Lin, Y.K., Yin, L.M., WANG, Z.H., WANG, Z.Z., YANG, J.D. \& WANG, Y.X. 1988. The recommended Cambrian-Ordovician global boundary stratotype of the Xiaoyangqiao section (Dayangcha, Jilin Province), China. Geological Magazine 125(4), 415-444. DOI 10.1017/S0016756800013054

Chen, J.Y., Zhang, J.M., Nicoll, R.S. et al. 1995. Carbon and oxygen isotopes in carbonate rocks within Cambrian-Ordovician boundary interval at Dayangcha, China. Acta Palaeontologica Sinica 34(4), 393-409.

CoOK, H.E. \& TAYLOR, M.E. 1977. Comparison of continental slope and shelf environments in the Upper Cambrian and lowest Ordovician of Nevada, 51-81. In Cоок, H.E. \& ENos, P. (eds) Deep-water carbonate environments. SEPM (Society for Sedimentary Geology) Special Publication 25.

Cook, H.E., Taylor, M.E. \& Miller, J.F. 1989. Day 2: Late Cambrian and Early Ordovician stratigraphy, biostratigraphy and depositional environments, Hot Creek Range, Nevada, 28-36. In TAYLOR, M.E. (ed.) Cambrian and Early Ordovician Stratigraphy and Paleontology of the Basin and Range Province, Western United States, Guidebook for Field Trip T125, $28^{\text {th }}$ International Geological Congress.

CoOper, R.A., Nowlan, G.S. \& Williams, S.H. 2001. Global Stratotype Section and Point for base of Ordovician System. Episodes 24(1), 19-28.

Derby, J.R., Lane, H.R. \& NoRford, B.S. 1972. Uppermost Cambrian-basal Ordovician faunal succession in Alberta and correlation with similar sequences in western United States. $24^{\text {th }}$ International Geological Congress, Montreal, Proceedings, Section 7, 503-512.

Ding, L.S., BaO, D.X. \& CAO, H.H. 1988. Study on the Cambrian-Ordovician conodonts from Zhuli, Zhejiang. Geological Review 34(4), 322-327.

Dong, X.P. 1984. Conodont-based Cambrian-Ordovician boundary at Huanghuachang of Yichang, Hubei, 383-415. In NANJING Institute of Geology and Palaeontology, Academia Sinica (ed.) Stratigraphy and Palaeontology of Systemic Boundaries in China, Cambrian-Ordovician Boundaries 2. Anhui Science and Technology Publishing House, Hefei.

DonG, X.P. 1987. Late Cambrian and Early Ordovician conodonts from Chuxian, Anhui, 135-184. In NANJing Institute OF Geology and Palaeontology, Academia Sinica (ed.) Collection of Postgraduate Theses 1. Jiangsu Science and Technology Publishing House, Nanjing.

Dong, X.P., RePetski, J.E. \& Bergström, S.M. 2004. Conodont biostratigraphy of the Middle Cambrian through lowermost Ordovician in Hunan, South China. Acta Geologica Sinica (English Edition) 78(6), 1185-1206.

Dubinina, S.V. 2001. Conodonts and zonal stratigraphy of the Cambrian-Ordovician boundary deposits. Trudy-Rossiyskaya Akademiya Nauk, Geologicheskiy Institut 517, 1-239.

FreEMAN, R.L. \& MiLLER, J.F. 2011. First report of a larval shell repair scar on a lingulate brachiopod: Evidence of shell-breaking predation in the Cambrian pelagic realm? Journal of Paleontology 85(4), 697-704. DOI 10.1666/10-160.1

Freeman, R.L. \& MilleR, J.F. In press. Lingulate brachiopods from the Upper Cambrian (Sunwaptan) Hellnmaria Member of the Notch Peak Formation, western Utah, USA. Memoirs of the Association of Australasian Palaeontologists 42, 37-74.

FreEMAN, R.J. \& STITT, J.H. 1996. Upper Cambrian and lowest Ordovician articulate brachiopods from the Arbuckle and Wichita Mountains, Oklahoma. Journal of Paleontology 70(3), 355-372.

Furnish, W.M. 1938. Conodonts from the Prairie du Chien beds of the upper Mississippi Valley. Journal of Paleontology 12, $318-340$.

Ghaderi, A., Aghanabati, A., Hamdi, B. \& Miller, J.F. 2008. Biostratigraphy of the first and second members of the type section of the Shirgesht Formation in north of Tabas with special emphasis on conodonts. Geosciences: Scientific Quarterly Journal, Ministry of Industries and Mines, Geological Survey of Iran, 17(67), 150-163. [in Farsi]

GRANT, R.E. 1965. Faunas and stratigraphy of the Snowy Range Formation, southwestern Montana and northwestern Wyoming. Geological Society of America Memoir 96, 1-171.

Hall, J. \& Whitfield, R.P. 1877. Paleontology. United States Geological Exploration of the $40^{\text {th }}$ Parallel Report, 199-231.

HeIn, F.J. \& Nowlan, G.S. 1998. Regional sedimentology, conodont biostratigraphy, and correlation of the Middle Cambrian-Lower Ordovician(?) strata of the "Finnegan" and Deadwood formations, Alberta subsurface, Western Canada. Bulletin of Canadian Petroleum Geology 46, 166-188.

Heredia, S. 1999. Los paraconodontes del Cámbrico Superior del cerro Pelado, Precordillera de Mendoza, Argentina. Ameghiniana 36(3), 345-358.

Hintze, L.F. 1951. Lower Ordovician detailed stratigraphic sections for western Utah. Utah Geological and Mineralogical Survey Bulletin 39, 1-99.

Hintze, L.F. 1974. Preliminary geologic map of The Barn quadrangle, Millard County, Utah. U.S. Geological Survey Miscellaneous Field Studies Map MF-633, scale 1:48,000, 2 sheets.

HintZE, L.F. \& DAvis, F.D. 2002. Geologic map of the Wah Wah Mountains North $30^{\prime} \times 60^{\prime}$ quadrangle and part of the Garrison $30^{\prime} \times 60^{\prime}$ quadrangle, southwest Millard County and part of Beaver County, Utah. Utah Geological Survey, Map 182, scale 1:100,000, 2 sheets.

Hintze, L.F. \& Kowalis, B.J. 2009. Geologic History of Utah. Brigham Young University Geology Studies, Special Publication 9, 1-225.

Hintze, L.F., Taylor, M.E. \& Miller, J.F. 1988. Upper Cambrian-Lower Ordovician Notch Peak Formation in western Utah. U.S. Geological Survey Professional Paper 1393, 1-30.

Holmer, L.E., Popov, L.E., Streng, M. \& Miller, J.F. 2005. Lower Ordovician (Tremadocian) lingulate brachiopods from the House and Fillmore formations, Ibex area, western Utah, USA. Journal of Paleontology 79(5), 884-906.

DOI 10.1666/0022-3360(2005)079[0884:LOTLBF]2.0.CO;2

Hughes, N.C. \& Hesselbo, S.P. 1997. Stratigraphy and sedimentology of the St. Lawrence Formation, Upper Cambrian of the Northern Mississippi Valley. Milwaukee Public Museum Contributions in Biology and Geology 91, 1-50.

Ivata, K., Sennikov, N.V., Buslov, M.M., Obut, O.T., ShokalSkit, S.P., Kusnetsov, S.A. \& ERmikov, V.D. 1997. Latter Cambrian-Early Ordovician age of the Zasur'ia basalt-siliceous-terrigenous Formation (northwestern Gorny Altai). Geologya i Geofizika, Siberian branch of Russian Academy of Sciences 38(9), 1427-1444. 
James, N.P. \& Stevens, R.K. 1986. Stratigraphy and correlation of the Cambro-Ordovician Cow Head Group, western Newfoundland. Geological Survey of Canada Bulletin 366, 1-143.

Jensen, R.G. 1967. Ordovician brachiopods from the Pogonip Group of Millard County, western Utah. Brigham Young University Geology Studies 14, 67-100.

Jing, X.C., Deng, S.H., Zhao, Z.J., Lu, Y.Z. \& Zhang, S.B. 2008. Carbon isotope composition and correlation across the Cambrian-Ordovician boundary in Kalpin Region of the Tarim Basin, China. Science in China Series D: Earth Science 51(9), 1317-1329. DOI 10.1007/s11430-008-0093-5

Kaljo, D., Borovko, N., Heinsalu, H., Khazanovich, K., Mens, K., Popov, L., Sergeyeva, S., Sobolevskaya, R. \& ViIra, V. 1986. The Cambrian-Ordovician boundary in the BalticLadoga Clint area (North Estonia and Leningrad Region, USSR). Proceedings of the Academy of Sciences of the Estonian SSR, Geology 35(3), 97-108.

Kanygin, A.V., Moskalenko, T.A., Yadrenkina, A.G., Abaimova, G.P., Semenova, V.S., Sychev, O.V. \& TimoKhin, A.V. 1989. Ordovik Sibirskoi platformy. Fauna $i$ stratigrafia Lenskoi fatchialnoi zony. 216 pp. Nauka, Novosibirsk.

Kobayashi, T. 1935. The Cambro-Ordovician formations and faunas of South Chosen, Palaeontology, Part 3, Cambrian faunas of South Chosen with a special study on the Cambrian trilobite genera and families. Journal of the Faculty of Science, Imperial University of Tokyo, Section II(4), 49-344.

Koneva, S.P. \& Popov, L.E. 1988. Akrotretidy (bezzamkovye brakhiopody) iz pogranichnykh otlozhenij kembriya-ordovika khrebta Malyj Karatau (Yuzhnyj Kazakhstan), 52-72. In Kolobova, I.M. \& Khozatski,, L.I. (eds) Ezhegodnik Vsesoyuznogo Paleontologicheskogo Obshchestva 31. [in Russian]

KuRTZ, V.E. \& MiLLER, J.F. 1978. Correlation of Lower Ordovician conodont Faunas D and E between Washington Land, western North Greenland and western United States. Geological Society of America, Abstracts with Programs 10(5), 219.

LANDING, E. 1983. Highgate Gorge: Upper Cambrian and Lower Ordovician continental slope deposition and biostratigraphy, northwestern Vermont. Journal of Paleontology 57(6), $1149-1187$.

LANDING, E. 1993. Cambrian-Ordovician boundary in the Taconic Allochthon, eastern New York, and its interregional correlation. Journal of Paleontology 67(1), 1-19.

Landing, E., Ludvigsen, R. \& von BitTer, P. 1980. Upper Cambrian to Lower Ordovician conodont biostratigraphy and biofacies, Rabitkettle Formation, District of Mackenzie. Royal Ontario Museum Life Sciences Contributions 126, 1-42.

Landing, E., Westrop, S.R. \& Adrain, J.M. 2011. The Lawsonian Stage - the Eoconodontus notchpeakensis (Miller, 1969) FAD and HERB carbon isotope excursion define a globally correlatable terminal Cambrian stage. Bulletin of Geosciences 86(3), 621-640. DOI 10.3140/bull.geosci.1151

Landing, E., Westrop, S.R. \& KePpie, J.D. 2007. Terminal Cambrian and lowest Ordovician succession of Mexican West Gondwana - biotas and sequence stratigraphy of the Tiñu Formation. Geological Magazine 144, 909-936.

Landing, E., Westrop, S.R., Kröger, B. \& English, A.M. 2011. Left behind - delayed extinction and a relict trilobite fauna in the Cambrian-Ordovician boundary succession (east Laurentian platform, New York). Geological Magazine 148(4), 529-557. DOI 10.1017/S0016756810000919
LANDing, E., Westrop, S.R. \& Miller, J.F. 2010. Globally practical base of the uppermost Cambrian (Stage 10) - FAD of the conodont Eoconodontus notchpeakensis and the Housian Stage. In FATKA, O. \& Budil, P. (eds) The $15^{\text {th }}$ Field Conference of the Cambrian Stage Subdivision Working Group. International Subcommission on Cambrian Stratigraphy. Abstracts and Excursion Guide, Prague, Czech Republic and southeastern Germany. Czech Geological Survey, Prague.

LEE, B.S. 2002. Conodonts from the Upper Cambrian Sesong and Hwajeol formations in the Sabuk area, South Korea. Acta Geologica Sinica 76(2), 155-165.

Lee, B.S., Lee, Y.I., Miller, J.F. \& Jeong, H. 2009. Conodont fauna of the Machari Formation (Middle and Upper Cambrian), Yeongweol Area, Gangweon Province, Korea. Ameghiniana 46(2), 407-430.

LongaCRE, S.A. 1970. Trilobites of the Upper Cambrian Ptychaspid Biomere, central Texas. Paleontological Society Memoir 4, 1-70.

Lu, Y.H. \& LiN, H.L. 1984. On the Cambrian-Ordovician boundary of the Jiangshan-Changshan area, W Zhejiang, 9-44. In Nanjing Institute of Geology and Palaeontology, AcadeMIA Sinica (ed.) Stratigraphy and Palaeontology of Systemic Boundaries in China, Cambrian-Ordovician Boundaries 1. Anhui Science and Technology Publishing House, Hefei.

Ludvigsen, R. 1982. Upper Cambrian and Lower Ordovician trilobite biostratigraphy of the Rabbitkettle Formation, western District of Mackenzie. Royal Ontario Museum Life Sciences Contributions 134, 1-188.

Ludvigsen, R. \& Westrop, S.R. 1983. Trilobite biofacies in the Cambrian-Ordovician boundary interval in northern North America. Alcheringa 7, 301-319. DOI 10.1080/03115518308619614

Ludvigsen, R. \& WeStrop, S.R. 1986. Classification of the Late Cambrian trilobite Idiomesus Raymond. Canadian Journal of Earth Sciences 23(7), 300-307. DOI 10.1139/e86-033

Ludvigsen, R., Westrop, S.R. \& Kindle, C.H. 1989. Sunwaptan (Upper Cambrian) trilobites of the Cow Head Group, western Newfoundland, Canada. Palaeontographica Canadiana 6, $1-175$.

Miller, J.F. 1969. Conodonts from the Notch Peak Limestone (Cambro-Ordovician), House Range, Utah. Journal of Paleontology 43(2), 413-439.

MilleR, J.F. 1980. Taxonomic revisions of some Upper Cambrian and Lower Ordovician conodonts with comments on their evolution. The University of Kansas Paleontological Contributions, Paper 99, 1-43.

Miller, J.F. 1984. Cambrian and earliest Ordovician conodont evolution, biofacies, and provincialism, 34-68. In CLARK, D.L. (ed.) Conodont Biofacies and Provincialism, Geological Society of America Special Paper 196.

Miller, J.F., Ethington, R.L., Evans, K.R., Holmer, L.E., Loch, J.D., Popov, L.E., REPETSKI, J.E., RiPPERDAN, R.L. \& TAYLOR, J.F. 2006. Proposed stratotype for the base of the highest Cambrian stage at the first appearance datum of Cordylodus andresi, Lawson Cove section, Utah, USA. Palaeoworld 15(3-4), 385-405. DOI 10.1016/j.palwor.2006.10.017

Miller, J.F., Evans, K.R. \& Dattilo, B.F. In press a. The Great American Carbonate Bank in the miogeocline of western central Utah: Tectonic influences on sedimentation. In DERBY, J.R., Fritz, R., Longacre, S.A., Morgan, W. \& Sternbach, 
C. (eds) The Great American Carbonate Bank: The Geology and Economic Resources of the Cambro-Ordovician Sauk Sequence of Laurentia, American Association of Petroleum Geologists Memoir 98.

Miller, J.F., Evans, K.R., J. Loch, J.D., Ethington, R.L. \& StitT, J.H. 2001. New lithostratigraphic units in the Notch Peak and House formations (Cambrian-Ordovician), Ibex Area, western Millard County, Utah. Brigham Young University Geology Studies 46, 35-69.

Miller, J.F., Evans, K.R., Loch, J.D., Ethington, R.L., StitT, J.H., Holmer, L.E. \& Popov, L.E. 2003. Stratigraphy of the Sauk III interval (Cambrian-Ordovician) in the Ibex area, western Millard County, Utah. Brigham Young University Geology Studies 47, 23-118.

Miller, J.F., Loch, J.D. \& TAYLOR, J.F. In press b. Biostratigraphy of Cambrian and Lower Ordovician strata in the Llano Uplift, central Texas. In Derby, J.R., Fritz, R., Longacre, S.A., Morgan, W. \& Sternbach, C. (eds) The Great American Carbonate Bank: The Geology and Economic Resources of the Cambro-Ordovician Sauk Sequence of Laurentia, American Association of Petroleum Geologists Memoir 98.

Miller, J.F. \& RePETski, J.E. 2009. Base of the Cordylodus proavus Zone (FAD of Cordylodus andresi) as a key horizon for Late Cambrian global chronocorrelation, 32-33. In HeNDERSON, C.M. \& MAClean, C. (eds) Abstracts of talks presented at the 2009 International Conodont Symposium, Permophyles (Newsletter of the Subcommission on Permian Stratigraphy) 53(1).

Miller, J.F., TAYlOR, M.E., STitT, J.H., Ethington, R.L., HintZe, L.F. \& TAYLOR, J.F. 1982. Potential Cambrian-Ordovician boundary stratotype sections in the western United States, 155-180. In BassetT, M.G. \& DeAn, W.T. (eds) The Cambrian-Ordovician boundary: Sections, fossils distributions, and correlations, National Museum of Wales Geological Series 3 .

MülleR, K.J. 1973. Late Cambrian and Early Ordovician conodonts from northern Iran. Geological Survey of Iran, Report $30,1-77$.

MülleR, K.J. \& Hinz, I. 1991. Upper Cambrian conodonts from Sweden. Fossils and Strata 28, 1-153.

Myrow, P.M., Taylor, J.F., Miller, J.F., Ethington, R.L., RipPeRDAn, R.L. \& Allen, J. 2003. Fallen arches: Dispelling myths concerning Cambrian and Ordovician paleogeography of the Rocky Mountain region. Geological Society of America Bulletin 115, 695-713.

DOI 10.1130/0016-7606(2003)115<0695:FADMCC >2.0.CO;2

Myrow, P.M., Taylor, J.F., Miller, J.F., Ethington, R.L., RiPPERDAN, R.L. \& BRACHLE, C.M. 1999. Stratigraphy, sedimentology, and paleontology of the Cambrian-Ordovician of Colorado, 157-176. In LAGESON, D.R., Lester, A.P. \& TRUdGILL, B.D. (eds) Colorado and Adjacent Areas: Boulder, Colorado, Geological Society of America Field Guide 1.

Nicoll, R.S. \& Shergold, J.H. 1991. Revised Late Cambrian (pre-Payntonian-Datsonian) conodont biostratigraphy at Black Mountain, Georgina Basin, western Queensland. BMR Journal of Australian Geology \& Geophysics 12, 93-118.

Nicoll, R.S., Miller, J.F., Nowlan, G.S., RePetski, J.E. \& Ethington, R.L. 1999. Iapetonudus (n. gen.) and Iapetognathus Landing, unusual earliest Ordovician multielement conodont taxa and their utility for biostratigraphy. Brigham Young University Geology Studies 44, 27-101.

Nowlan, G.S. 1985. Late Cambrian and Early Orovician conodonts from the Franklinian Miogeosyncline, Canadian Arctic Islands. Journal of Paleontology 59, 96-122.

ORNDORFF, R.C. 1988. Latest Cambrian and earliest Ordovician conodonts from the Conococheague and Stonehenge Limestones of northwestern Virginia. United States Geological Survey Bulletin 1837, A1-A23.

ÖzGUL, N. \& GEDIK, N. 1973. New data on the stratigraphy and conodont faunas of the Çaltape Limestone and the Seydisehir Formation, lower Paleozoic of central Taurus Range. Bulletin of the Geological Society of Turkey 16(2), 39-52.

PANDER, C.H. 1856. Monographie der fossilen Fische des silurischen Systems der russische-baltischen Gouvernements. 91 pp. Buchdruckeri der Kaiserlichen Akedemie der Wissenschaften, St. Petersburg.

Popov, L.E., Holmer, L.E. \& Miller, J.F. 2002. Lingulate brachiopods from the Cambrian-Ordovician boundary beds of Utah. Journal of Paleontology 76, 211-228.

DOI 10.1666/0022-3360(2002)076<0211:LBFTCO >2.0.CO;2

Popov, L.E. \& Tolmacheva, T.Y. 1995. Conodont distribution in a deep-water Cambrian-Ordovician boundary sequence from south-central Kazakhstan, 121-124. In COOPER, J.D., Droser, M.L. \& Finney, S.C. (eds) Ordovician Odyssey: Short Papers for the Seventh International Symposium on the Ordovician System. Pacific Section SEPM, Fullerton, California.

RIPPERDAN, R.L. 2002. The HERB Event: End of Cambrian carbon cycle paradigm? Geological Society of America, Abstracts with Programs 34(6), 413.

RipPerdan, R.L., Magaritz, M. \& KirschVinK, J.L. 1993. Carbon isotope and magnetic polarity evidence for non-depositional events within the Cambrian-Ordovician boundary section at Dayangcha, Jilin Province, China. Geological Magazine 130(4), 443-452. DOI 10.1017/S0016756800020525

RipPerdan, R.L., Magaritz, M., Nicoll, R.S. \& Shergold, J.S. 1992. Simultaneous changes in carbon isotopes, sea level, and conodont biozones within the Cambrian-Ordovician boundary interval at Black Mountain, Australia. Geology 20, 1039-1042.

DOI 10.1130/0091-7613(1992)020<1039:SCICIS >2.3.CO;2

RIPPERDAN, R.L. \& MiLLER, J.F. 1995. Carbon isotope ratios from the Cambrian-Ordovician boundary section at Lawson Cove, Ibex area, Utah, 129-132. In CoOPER, J.D., Droser, M.L. \& FINNEY, S.C. (eds) Ordovician Odyssey: Short Papers for the Seventh International Symposium on the Ordovician System. Pacific Section SEPM, Fullerton, California.

Ross, R.J., JR., Hintze, L.F., Ethington, R.L., Miller, J.F., TAYlor, M.E., RePETSKi, J.E., SPRinKLE, J. \& GuensbuRG, T.E. 1997. The Ibexian, lowermost series in the North American Ordovician, 1-50. In TAYLOR, M.E. (ed.) Early Paleozoic Biochronology of the Great Basin, Western United States, U.S. Geological Survey Professional Paper 1579.

Runkel, A.C., Miller, J.F., Mckay, R.M., Palmer, A.R. \& TAYLOR, J.F. 2007. High-resolution sequence stratigraphy of lower Paleozoic sheet sandstones in central North America: The role of special conditions of cratonic interiors in development of stratal architecture. Geological Society of America Bulletin 119, 860-881. DOI 10.1130/B26117.1

SeArs, J.W. \& PricE, R.A. 2003. Tightening the Siberian connec- 
tion to western Laurentia. Geological Society of America Bulletin 115, 943-953. DOI 10.1130/B25229.1

StitT, J.H. 1971. Late Cambrian and earliest Ordovician trilobites, Timbered Hills and Lower Arbuckle groups, western Arbuckle Mountains, Murray County, Oklahoma. Oklahoma Geological Survey Bulletin 110, 1-83.

StiTT, J.H. 1977. Late Cambrian and earliest Ordovician trilobites, Wichita Mountains area, Oklahoma. Oklahoma Geological Survey Bulletin 124, 1-79.

SZANIAWSKI, H. 2002. New evidence for the protoconodont origin of chaetognaths. Acta Palaeontologica Polonica 47(3), 405-419.

Szaniawski, H. \& Bengtson, S. 1998. Late Cambrian euconodonts from Sweden. Palaeontologica Polonica 58, 9-29.

TAylor, J.F., Brezinski, D.K., RePeTSKi, J.E. \& Welsh, N.M. 2009. The Adamstown Submergence Event: Faunal and sedimentological record of a Late Cambrian (Furongian) transgression in the Appalachian region. Memoirs of the Association of Australasian Palaeontologists 37, 641-667.

TAylor, J.F., Kennedy, D.J., Miller, J.F. \& RePETSKi, J.E. 1991. Uppermost Cambrian slope deposits at Highgate Gorge, Vermont: A minor miscorrelation with major consequences for conodont- and trilobite-based chronocorrelation. Journal of Paleontology 65, 855-863.

TAYLOR, J.F. \& REPETSKI, J.E. 1995. High-resolution trilobite and conodont biostratigraphy across the Cambrian-Ordovician boundary in south-central New Mexico, 133-136. In CoOPER, J.D., Droser, M.L. \& Finney, S.C. (eds) Ordovician Odyssey: Short Papers for the Seventh International Symposium on the Ordovician System. Pacific Section SEPM, Fullerton, California.

TAYloR, J.F., RePETSKI, J.E., Loch, J.D. \& LeSLIE, S.A. In press. Biostratigraphy and Chronostratigraphy of the Great American Carbonate Bank. In Derby, J.R., Fritz, R., Longacre, S.A., Morgan, W. \& Sternbach, C. (eds) The Great American Carbonate Bank: The Geology and Economic Resources of the Cambro-Ordovician Sauk Sequence of Laurentia, American Association of Petroleum Geologists Memoir 98.

TAYLOR, J.F., REPETSKI, J.E. \& ORNDORFF, R.C. 1992. The Stonehenge transgression: A rapid submergence of the central Appalachian platform in the Early Ordovician, 409-418. In Webby, B.D. \& Laurie, J.R. (eds) Global Perspectives on Ordovician Geology, Balkema, Rotterdam.

TAYLOR, J.F., RePETSKI, J.E. \& RoEBUCK, C.A. 1996. Stratigraphic significance of trilobite and conodont faunas from the Cambrian-Ordovician shelfbreak facies in the Frederick Valley, Maryland, 141-164. In BREZINSKI, D.K. \& Reger, J.P. (eds) Studies in Maryland Geology, Maryland Geological Survey Special Publication 3.

Taylor, M.E., CoOK, H.E. \& Miller, J.F. 1989. Day 3: Late Cambrian and Early Ordovician biostratigraphy and depositional environments of the Whipple Cave Formation and House Limestone, Central Egan Range, Nevada, 37-44. In TAYLOR, M.E. (ed.) Cambrian and Early Ordovician Stratigraphy and Paleontology of the Basin and Range Province, Western United States: Guidebook for Field Trip T125, $28^{\text {th }}$ International Geological Congress.

Tipnis, R.S., Chatterton, B.D.E. \& Ludvigsen, R. 1979. Ordovician conodont biostratigraphy of the southern District of Mackenzie, Canada, 39-91. In Stelck, C.R. \& Chatterton, B.D.E. (eds) Western and Arctic Canadian Biostratigraphy, Geological Association of Canada Special Paper 18.
Ulrich, E.O. \& COOPER, G.A. 1936. New genera and species of Ozarkian and Canadian brachiopods. Journal of Paleontology 10, 616-631.

ULrich, E.O. \& COOPER, G.A. 1938. New species of Ozarkian and Canadian brachiopods. Geological Society of America Special Paper 13, 1-323.

Vendrasco, M.J. \& RunNegar, B. 2004. Late Cambrian and early Ordovician stem group chitons (Mollusca, Polyplacophora) from Utah and Missouri. Journal of Paleontology 78, 675-689.

DOI 10.1666/0022-3360(2004)078<0675:LCAEOS >2.0.CO;2

VirRa, V., Sergeyeva, S. \& Popov, L. 1987. Earliest representatives of the genus Cordylodus (Conodonta) from the CambroOrdovician boundary beds of North Estonia and Leningrad Region. Proceedings of the Academy of Sciences of the Estonian SSR, Geology 36(4), 145-153.

WANG, Z.H. 1984. Late Cambrian and Early Ordovician conodonts from North and Northeast China with comments on the Cambrian-Ordovician boundary, 176-272. In NANJING INSTItute of Geology and Palaeontology, Academia Sinica (ed.) Stratigraphy and Palaeontology of Systemic Boundaries in China, Cambrian-Ordovician Boundaries 2. Anhui Science and Technology Publishing House, Hefei.

WalcotT, C.D. 1884. Paleontology of the Eureka district, Nevada. United States Geological Survey Monograph 8, 1-298.

WalcotT, C.D. 1905. Cambrian Brachiopoda; Descriptions of new genera and species. United States National Museum Proceedings 28, 227-337.

WaLcotT, C.D. 1908a. Nomenclature of some Cambrian Cordilleran formations. Smithsonian Miscellaneous Collections $53(1), 1-12$.

WaLCotT, C.D. 1908b. Cambrian sections of the Cordilleran area. Smithsonian Miscellaneous Collections 53(4), 167-230.

WalcotT, C.D. 1908c. Cambrian geology and paleontology; Number 3 - Cambrian Brachiopoda, descriptions of new genera and species. Smithsonian Miscellaneous Collections 53(3), 53-165.

WestroP, S.R. 1986. Trilobites of the Upper Cambrian Sunwaptan Stage, southern Canadian Rocky Mountains, Alberta. Palaeontographica Canadiana 3, 1-179.

Westrop, S.R., Adrain, J.M. \& Landing, E. 2011. The Cambrian (Sunwaptan, Furongian) agnostoid arthropod Lotagnostus Whitehouse, 1936, in Laurentian and Avalonian North America: systematics and biostratigraphic significance. Bulletin of Geosciences 86(3), 569-594. DOI 10.3140.bull.geosci.1256

Westrop, S.R., LANDing, E. \& Ludvigsen, R. 1981. Upper Cambrian and Lower Ordovician trilobite and conodont biostratigraphy, Wilcox Peak, Jasper National Park, Alberta, 45-58. In TAYLOR, M.E. (ed.) The Cambrian System in the southern Canadian Rocky Mountains, Alberta and British Columbia, Second International Symposium on the Cambrian System, Guidebook for Field Trip 2.

Winston, D. \& Nicholls, H. 1967. Late Cambrian and Early Ordovician faunas from the Wilberns Formation of Central Texas. Journal of Paleontology 41(1), 66-96.

Wu, G.C., YAo, J.X., Ji, Z.S. \& Liu, S.C. 2005. Latest biostratigraphic advances of Cambrian-Ordovician boundary in Qingzhou area, Shandong. Acta Paleontologica Sinica 44(1), 106-116. 